\title{
The mechanism of cell death induced by silver nanoparticles is distinct from silver cations
}

\author{
Monica M. Rohde ${ }^{1}$, Christina M. Snyder ${ }^{1}$, John Sloop ${ }^{2}$, Shane R. Solst ${ }^{3}$, George L. Donati ${ }^{2}$, Douglas R. Spitz ${ }^{3}$, \\ Cristina M. Furdui ${ }^{4,5}$ and Ravi Singh ${ }^{1,5^{*}}$ (D)
}

\begin{abstract}
Background: Precisely how silver nanoparticles (AgNPs) kill mammalian cells still is not fully understood. It is not clear if AgNP-induced damage differs from silver cation $\left(\mathrm{Ag}^{+}\right)$, nor is it known how AgNP damage is transmitted from cell membranes, including endosomes, to other organelles. Cells can differ in relative sensitivity to AgNPs or $\mathrm{Ag}^{+}$, which adds another layer of complexity to identifying specific mechanisms of action. Therefore, we determined if there were specific effects of AgNPs that differed from $\mathrm{Ag}^{+}$in cells with high or low sensitivity to either toxicant.

Methods: Cells were exposed to intact AgNPs, $\mathrm{Ag}^{+}$, or defined mixtures of $\mathrm{AgNPs}_{\text {with }} \mathrm{Ag}^{+}$, and viability was assessed. The level of dissolved $\mathrm{Ag}^{+}$in AgNP suspensions was determined using inductively coupled plasma mass spectrometry. Changes in reactive oxygen species following AgNP or $\mathrm{Ag}^{+}$exposure were quantified, and treatment with catalase, an enzyme that catalyzes the decomposition of $\mathrm{H}_{2} \mathrm{O}_{2}$ to water and oxygen, was used to determine selectively the contribution of $\mathrm{H}_{2} \mathrm{O}_{2}$ to $\mathrm{AgNP}$ and $\mathrm{Ag}^{+}$induced cell death. Lipid peroxides, formation of 4-hydroxynonenol protein adducts, protein thiol oxidation, protein aggregation, and activation of the integrated stress response after AgNP or $\mathrm{Ag}^{+}$exposure were quantified. Lastly, cell membrane integrity and indications of apoptosis or necrosis in $\mathrm{AgNP}$ and $\mathrm{Ag}^{+}$treated cells were examined by flow cytometry.
\end{abstract}

Results: We identified AgNPs with negligible $\mathrm{Ag}^{+}$contamination. We found that SUM159 cells, which are a triplenegative breast cancer cell line, were more sensitive to AgNP exposure less sensitive to $\mathrm{Ag}^{+}$compared to iMECs, an immortalized, breast epithelial cell line. This indicates that high sensitivity to AgNPs was not predictive of similar sensitivity to $\mathrm{Ag}^{+}$. Exposure to AgNPs increased protein thiol oxidation, misfolded proteins, and activation of the integrated stress response in AgNP sensitive SUM159 cells but not in iMEC cells. In contrast, $\mathrm{Ag}^{+}$cause similar damage in $\mathrm{Ag}^{+}$ sensitive iMEC cells but not in SUM159 cells. Both $\mathrm{Ag}^{+}$and AgNP exposure increased $\mathrm{H}_{2} \mathrm{O}_{2}$ levels; however, treatment with catalase rescued cells from $\mathrm{Ag}^{+}$cytotoxicity but not from AgNPs. Instead, our data support a mechanism by which damage from AgNP exposure propagates through cells by generation of lipid peroxides, subsequent lipid peroxide mediated oxidation of proteins, and via generation of 4-hydroxynonenal (4-HNE) protein adducts.

Conclusions: There are distinct differences in the responses of cells to AgNPs and $\mathrm{Ag}^{+}$. Specifically, AgNPs drive cell death through lipid peroxidation leading to proteotoxicity and necrotic cell death, whereas $\mathrm{Ag}^{+}$increases $\mathrm{H}_{2} \mathrm{O}_{2}$, which drives oxidative stress and apoptotic cell death. This work identifies a previously unknown mechanism by

\footnotetext{
*Correspondence: rasingh@wakehealth.edu

${ }^{1}$ Department of Cancer Biology, Wake Forest School of Medicine, Medical Center Blvd., Winston-Salem, NC 27157, USA
}

Full list of author information is available at the end of the article permits use, sharing, adaptation, distribution and reproduction in any medium or format, as long as you give appropriate credit to the original author(s) and the source, provide a link to the Creative Commons licence, and indicate if changes were made. The images or other third party material in this article are included in the article's Creative Commons licence, unless indicated otherwise in a credit line to the material. If material is not included in the article's Creative Commons licence and your intended use is not permitted by statutory regulation or exceeds the permitted use, you will need to obtain permission directly from the copyright holder. To view a copy of this licence, visit http://creativecommons.org/licenses/by/4.0/. The Creative Commons Public Domain Dedication waiver (http://creativeco mmons.org/publicdomain/zero/1.0/) applies to the data made available in this article, unless otherwise stated in a credit line to the data. 
which AgNPs kill mammalian cells that is not dependent upon the contribution of $\mathrm{Ag}^{+}$released in extracellular media. Understanding precisely which factors drive the toxicity of AgNPs is essential for biomedical applications such as cancer therapy, and of importance to identifying consequences of unintended exposures.

Keywords: Nanotoxicology, Oxidative stress, Lipid peroxidation, Biosafety, Breast cancer

\section{Introduction}

Silver nanoparticles (AgNPs) are one of the most commercialized nanomaterials for biomedical and industrial applications, and extensive analysis of their toxicity has been performed in a wide variety of organisms $[1,2]$. Despite this, precisely how AgNPs kill mammalian cells still is not known. There continues to be debate over whether cytotoxic effects of AgNPs are due to uptake of intact nanoparticles or due to extracellular release of silver cation $\left(\mathrm{Ag}^{+}\right)$. Understanding precisely which factors drive the toxicity of AgNPs is essential to guide their utility for biomedical applications and to identify consequences of unintended exposures.

A major contributing factor to the lack of a definitive answer in the particle versus cation debate is poor material characterization. In many studies, there is a substantial amount of $\mathrm{Ag}^{+}$remaining in the AgNP suspension due to lack of purification following synthesis [3, 4]. Because of this, multiple studies conclude that $\mathrm{Ag}^{+}$is the dominant toxicant present in mixtures of intact AgNPs and $\mathrm{Ag}^{+}$[5-7]. Release of $\mathrm{Ag}^{+}$also can occur due to dissolution of AgNPs in culture media, and Teeguarden and colleagues determined that extracellular release of $\mathrm{Ag}^{+}$ was sufficient to drive cytotoxic responses of murine macrophages to AgNP exposure [8]. It will be necessary to use preparations of AgNPs with negligible contamination with $\mathrm{Ag}^{+}$to disambiguate fully the contributions to cytotoxicity of intact AgNPs and dissolved $\mathrm{Ag}^{+}$.

A second issue that must be addressed to obtain a definitive answer to the AgNP versus $\mathrm{Ag}^{+}$debate is the heterogeneity of the inherent sensitivity of various types of cells to AgNP suspensions. For example, previous studies show that some breast cancer cell lines are more sensitive to AgNP exposure than non-neoplastic mammary epithelial cells [9-11]. Similarly, there is substantial variability in the sensitivity of ovarian cancer [12], lung cancer $[13,14]$, and leukemia cell lines [15] to AgNP exposure. Our previous recent results show that sensitivity to $\mathrm{Ag}^{+}$exposure does not correlate with sensitivity to intact AgNPs [11]. This indicates that AgNPs and $\mathrm{Ag}^{+}$ may elicit different mechanistic responses in cells with high sensitivity compared to those with low sensitivity.

$\mathrm{Ag}^{+}$can be taken up by cells and enter the cytosol through copper ion transporters [16, 17], but AgNPs are too large to pass through ion channels, and instead are taken up by phagocytic and endocytic pathways [18].
After uptake, AgNPs appear to remain confined to membrane bound vesicles including early and late endosomes, and autophagosomes [11]. Despite this, AgNP-induced damage is observed in almost every part of the cell, including mitochondria [13, 14], nucleus [9], and endoplasmic reticulum $[10,11]$. A Trojan Horse mechanism has been proposed whereby AgNPs act as a vehicle that carries silver across the cell membrane followed by intracellular dissolution of AgNPs to release $\operatorname{Ag}^{+}[19,20]$, resulting in ROS production, DNA damage, proteotoxic stress, and apoptosis [21, 22]. Intracellular nanoparticle dissolution likely occurs, but if intracellular $\mathrm{Ag}^{+}$ release were the dominant mechanism of AgNP toxicity, then intracellular AgNP mass and surface area would be expected to correlate with sensitivity to AgNPs. This is not always the case $[8,11]$, indicating other factors may drive sensitivity to AgNPs.

Most studies agree that generation of reactive oxygen species (ROS) and induction of oxidative stress drive $\mathrm{Ag}^{+}$ cytotoxicity [23-26]. AgNPs also increase ROS [13] and cause oxidative damage to proteins $[9,11,13]$, but there is conflicting evidence regarding the dependency of AgNPinduced cytotoxicity on ROS [15, 27, 28]. Exposure to AgNPs also may increase lipid peroxides in earthworms [29], fish [30], and liver cancer cells [31]. Extensive oxidation of lipids disrupts the physical properties of cell membranes, can cause covalent modification of proteins, and can damage mitochondria and nucleic acids [32]. Lipid peroxides and $\mathrm{H}_{2} \mathrm{O}_{2}$ are capable of spreading damage throughout cells, but their relative importance in the toxicity of AgNPs and $\mathrm{Ag}^{+}$has not been studied.

It is not clear if AgNP-induced damage differs from that induced by $\mathrm{Ag}^{+}$, nor is it known how AgNP or $\mathrm{Ag}^{+}$ damage is transmitted from cell membranes, including endosomes, to other organelles. Therefore, the objectives of this work are: first, to determined if there are specific effects of AgNPs that differed from $\mathrm{Ag}^{+}$in cells with high or low sensitivity to either toxicant; second, to determine if AgNPs and $\mathrm{Ag}^{+}$cause similar or different forms of oxidative damage, cell stress, and cell death; and third, to determine if $\mathrm{H}_{2} \mathrm{O}_{2}$ or lipid peroxide generation differs between AgNPs and $\mathrm{Ag}^{+}$, and to assess their roles in transmission of damage. 


\section{Material and methods}

\section{Silver nanoparticles}

$25 \mathrm{~nm}$ in diameter spherical AgNPs stabilized with polyvinylpyrrolidone (PVP) were purchased from nanoComposix, Inc (San Diego, CA, USA). The manufacturer specified a mass ratio of $17 \%$ Ag to $83 \%$ PVP for the nanoparticles. Nanoparticles were dispersed at a concentration of $5 \mathrm{mg} / \mathrm{mL}$ (Ag mass, excluding PVP) in phosphate buffered saline, $\mathrm{pH}$ 7.4, without calcium or magnesium (PBS) (Invitrogen, Carlsbad, CA, USA) by bath sonication for $30 \mathrm{~min}$, and then were diluted in cell culture medium to the final concentration listed in the figures prior to addition to the wells containing cells.

\section{Cell culture}

SUM159 cells were purchased from Astrerand (now BioIVT, Westbury, NY, USA). iMEC cells were provided by Dr. Elizabeth Alli in the Department of Cancer Biology at Wake Forest School of Medicine. SUM159 cells expressing doxycycline inducible catalase (SUM159 ${ }^{\text {cat }}$ ) were generated as follows. Briefly, the doxycycline-inducible catalase overexpression plasmid was generated as previously described [33]. Lentivirus was produced in the TSA201 cell line using pCMV-VSV-G and psPAX2 helper vectors (Addgene, Caimbridge, MA, USA). Sum159 cells were plated and allowed to grow for $48 \mathrm{~h}$, and then virus was added to cells with $8 \mu \mathrm{g} / \mathrm{mL}$ of polybrene every $24 \mathrm{~h}$ for two days. After transduction, cells were selected with $3 \mu \mathrm{g} / \mathrm{mL}$ puromycin. Surviving cells were plated in $100-\mathrm{mm}$ dishes with 100 cells per dish. Clones were grown for 8 days, and then several colonies were picked and expanded. To test for maximal catalase overexpression, cells were treated with $2 \mu \mathrm{g} / \mathrm{mL}$ of doxycycline for $48 \mathrm{~h}$. Protein concentration was determined using the Lowry Assay. Increased catalase activity was verified by measuring the decomposition of $\mathrm{H}_{2} \mathrm{O}_{2}$ by cell lysates as previously described [34]. The clone with the greatest catalase activity following induction was selected for use in the current studies. Low passage stocks of cells were stored in liquid nitrogen and maintained by the Wake Forest Comprehensive Cancer Center Cell Engineering Shared Resource. iMEC cells were grown in DMEM/ F12 basal media (Lonza, Morristown, NJ, USA) supplemented with $10 \mu \mathrm{g} / \mathrm{ml}$ insulin, $20 \mathrm{ng} / \mathrm{ml} \mathrm{hEGF,} 0.5 \mu \mathrm{g} / \mathrm{ml}$ hydrocortisone (all from Sigma-Aldrich), and 10\% fetal bovine serum (FBS) (Gibco; ThermoFisher Scientific, Waltham, MA, USA). SUM159 and SUM159 ${ }^{\text {cat }}$ cells were grown in Hams F12 basal media (Lonza) supplemented with $5 \mu \mathrm{g} / \mathrm{ml}$ insulin, $10 \mathrm{mM}$ HEPES, and $1 \mu \mathrm{g} / \mathrm{ml}$ hydrocortisone (all from Sigma-Aldrich), and 5\% FBS (Gibco). SUM159 $9^{\text {cat }}$ cells were treated with $2 \mu \mathrm{g} / \mathrm{mL}$ of doxycycline $24 \mathrm{~h}$ before subsequent treatments to induce catalase expression and were maintained in doxycycline for the duration of each experiment. Cell monolayers were grown in tissue culture treated plastics purchased from Corning Life Sciences (Corning, NY, USA) or on glass coverslips (Warner Instruments Corporation, Hamden, CT, USA). Cells were provided fresh media and passaged twice weekly, and were maintained in culture for no longer than 3 months before new cultures were established from low passage frozen stocks. All cells were verified to be free from mycoplasma contamination by periodic testing using the MycoAlert Mycoplasma Detection Kit (Lonza, Morristown, NJ, USA).

\section{Nanoparticle characterization}

The hydrodynamic diameter of AgNPs in PBS or SUM159 cell culture media was determined using a Nanosight NS500 (Malvern Instruments, Malvern, UK) running NTA 3.2 Dev Build 3.2.16 software. Data were acquired by analyzing a $60 \mathrm{~s}$ video taken by the instrument with camera level 6 and a detection threshold of 7. Five measurements were obtained per sample. A Zetasizer Nano ZS90 (Malvern Instruments) running software version 7.12 was used for $\zeta$-potential measurements. Triplicate measurements were made for each sample.

\section{MTT assay}

Cells were seeded on 96 well plates at a density of 35005000 cells per well (depending upon cell line) in $100 \mu \mathrm{L}$ of complete media, recovered for $24 \mathrm{~h}$, and then were exposed to AgNPs or $\mathrm{AgNO}_{3}$ (Sigma-Aldrich) as a source of $\mathrm{Ag}^{+}$in $100 \mu \mathrm{L}$ of complete media containing the indicated concentrations of silver listed in the figures. After $72 \mathrm{~h}$, media containing AgNPs or $\mathrm{Ag}^{+}$were replaced with $200 \mu \mathrm{L}$ of media containing $0.5 \mathrm{mg} / \mathrm{mL} 3$-(4,5-dimethylthiazol-2-yl)-2,5-diphenyltetrazolium bromide (MTT; Sigma-Aldrich) and incubated for $2 \mathrm{~h}$ at $37 \mathrm{C}$. Media was removed, and cells were lysed in $200 \mathrm{uL}$ of DMSO and absorbance read using a Molecular Devices (San Jose, CA, USA) Emax Precision Microplate Reader at $595 \mathrm{~nm}$. To control for contributions to absorbance due to AgNPs, the absorbance of wells treated with AgNPs but which do not receive MTT also was measured. Comparisons of curve fitting and statistical analysis of background corrected and raw absorbance measurements fell within the standard deviation of normal sample variation, and therefore any contribution of AgNP absorbance was deemed negligible to the overall results.

\section{Western blots}

Cells were plated on $6 \mathrm{~cm}$ tissue culture dishes (Corning Life Sciences) at a density of $1 \times 10^{6}$ cells in $4 \mathrm{~mL}$ of complete medium. Cells were allowed to recover for $48 \mathrm{~h}$ and then were exposed to AgNPs or $\mathrm{Ag}^{+}$for $24 \mathrm{~h}$ at $37{ }^{\circ} \mathrm{C}$. Medium was removed and cells were washed 
twice with ice cold PBS before lysates were collected using Mammalian Protein Extraction Reagent (Thermo Fisher Scientific) supplemented with 1\% Halt Protease \& Phosphatase Inhibitor Cocktail (Thermo Fisher Scientific). Protein concentration was determined for each sample using a Pierce bicinchoninic acid (BCA) protein assay kit (Thermo Fisher Scientific) according to manufacturer's instructions. Proteins were size fractionated by gel electrophoresis and then transferred to a nitrocellulose; Thermo Fisher Scientific) membrane. Nonspecific binding was blocked by incubation for $30 \mathrm{~min}$ at room temperature with tris-buffered saline containing $5 \%$ bovine serum albumin (Sigma) or $5 \%$ blotting-grade blocker (Bio-Rad). Membranes were blotted overnight at $4{ }^{\circ} \mathrm{C}$ with $1: 1000$ dilutions of primary antibodies phospho-eIF2 $\alpha$ (9721), eIF2 $\alpha$ (9722), phospho-JNK (9255), JNK (9252), GAPDH (2118), $\beta$-actin (4970) purchased from Cell Signaling Technologies (Danvers, MA, USA), or 4-HNE (MAB3249-SP) purchased from Thermo Fisher Scientific, washed, and then incubated with antirabbit (Cell Signaling Technologies) or anti-mouse (Cell Signaling Technologies) horseradish peroxidase (HRP)conjugated secondary antibodies; (diluted 1:1000) for $1 \mathrm{~h}$ at room temperature. Immunoreactive products were visualized by chemiluminescence (SuperSignal West Pico Plus, Thermo Fisher Scientific). After visualization, blots were stripped of antibody binding by incubating with Restore Plus western blot stripping buffer (Thermo Fisher Scientific) for $5 \mathrm{~min}$, before blocking and re-probing with additional primary antibodies.

\section{Protein aggregation assays}

Cells were plated on $18 \mathrm{~mm}$ coverslips in a 12-well plate (Warner Instruments Corporation, Hamden, CT, USA) at a density of 250,000 cells in $1 \mathrm{~mL}$ of complete medium. Cells were allowed to recover for $72 \mathrm{~h}$ and then were exposed to AgNPs or $\mathrm{Ag}^{+}$for $24 \mathrm{~h}$ at $37 \mathrm{C}$. Medium was removed and cells were fixed with $4 \%$ formaldehyde solution and permeabilized $(0.5 \%$ Triton X-100, $3 \mathrm{~mm}$ EDTA, pH 8.0). Cells were then stained with Proteostat Aggresome Detection Reagent (1:1000) and Hoechst 33,342 (1:1000) (Enzo Biosciences, Ann Arbor, MI) diluted in 1X PBS for $30 \mathrm{~min}$, washed twice with PBS, and coverslips were mounted on glass slides with Prolong Gold antifade reagent (Invitrogen). Fluorescence was visualized using an Olympus FV1200 spectral laser scanning confocal microscope.

\section{Lipid peroxidation assays}

Cells were plated on $18 \mathrm{~mm}$ coverslips in a 12-well plate (Warner Instruments Corporation, Hamden, CT, USA) at a density of 250,000 cells in $1 \mathrm{~mL}$ of complete medium for microscopy experiments and on 6-well plates at a density of 500,000 cells per well in $2 \mathrm{~mL}$ of complete medium for flow cytometry experiments. Cells were allowed to recover for $24 \mathrm{~h}$ and then were exposed to AgNPs or $\mathrm{Ag}^{+}$for $24 \mathrm{~h}$ at $37{ }^{\circ} \mathrm{C}$. Medium was removed and fresh media containing $10 \mu \mathrm{M}$ of the lipid peroxide specific dye, Liperfluo (Dojindo Molecular Technologies, Rockville, MD,) was added for $30 \mathrm{~min}$. Cells were then washed twice with PBS and fluorescence was measured using an Olympus FV1200 spectral laser scanning confocal microscope and a FACS Canto II Analyzer (BD Biosciences). Analysis of the data was performed using FCS express version 7 (De Novo Software, Glendale, CA, USA).

\section{Protein oxidation assays}

Cells were plated on 6-well plates at a density of 500,000 cells per well in $2 \mathrm{~mL}$ of complete medium. Cells were allowed to recover for $24 \mathrm{~h}$ and then were exposed to AgNPs or $\mathrm{Ag}^{+}$for $24 \mathrm{~h}$ at $37 \mathrm{C}$. Medium was removed and fresh media containing $50 \mu \mathrm{M}$ of DCP-NEt ${ }_{2}$-Coumarin $\left(\mathrm{DCP}-\mathrm{NEt}_{2} \mathrm{C}\right)$ prepared as previously described [35] was added for $30 \mathrm{~min}$. Cells were then washed twice with PBS, fixed with $100 \%$ methanol and fluorescence was measured using a FACS Canto II Analyzer (BD Biosciences). Analysis of the data was performed using FCS express version 7 (De Novo Software, Glendale, CA, USA). To control for any potential contribution to the fluorescence profile due to AgNPs themselves, unstained AgNP treated and untreated cells were prepared and analyzed as described above. As shown in Additional file 1: Fig. S1A, the fluorescence profiles overlapped, indicating no difference between the two groups, and the magnitude of fluorescence was less than $0.5 \%$ of the DCP-NEt ${ }_{2} \mathrm{C}$ stained, untreated controls. Because these background measurements fell within the standard deviation of normal sample variation, any contribution of AgNP absorbance was deemed negligible to the overall results.

\section{Clonogenic assay}

Cells were grown to log phase in their respective media, trypsinized, washed in PBS, and plated on six-well plates at a density of 300 cells per well and were allowed to adhere for $24 \mathrm{~h}$. Increasing concentrations of AgNPs were added to each well and incubated for $24 \mathrm{~h}$ at $37^{\circ} \mathrm{C}$. For each condition, 6 wells were used. Cells were incubated with AgNPs with or without PEG-catalase (SigmaAldrich) $(100 \mathrm{U} / \mathrm{mL})$ for $24 \mathrm{~h}$, and then culture media was removed. The cells were washed with PBS, and fresh media was added and replaced every 2-3 days. Fourteen days after plating, the cells were washed and fixed with methanol, glacial acetic acid, and water (1:1:8 [vol:vol:vol]), then stained with crystal violet. Colonies of at least 50 cells were counted by hand. All data are 
expressed as plating efficiency relative to the relevant control in the absence of AgNPs.

\section{Transmission electron microscopy}

SUM159 or iMEC cells were grown in 6-well tissue culture dishes. Cells were treated with AgNPs $(150 \mu \mathrm{g} / \mathrm{mL})$ for $1 \mathrm{~h}$ and were washed thoroughly with PBS to remove AgNPs not bound or internalized by cells. Fresh cell culture media was added and cells were incubated for $5 \mathrm{~h}$ more before fixation in $2.5 \%$ gluteraldehyde at $4{ }^{\circ} \mathrm{C}$ overnight. Next, cells were scraped from the wells, pelleted, embedded in resin, cut into ultrathin sections $(80 \mathrm{~nm})$, and placed on copper coated formvar grids by the Wake Forest Comprehensive Cancer Center Cellular Imaging Shared Resource. Cells were imaged without additional staining to facilitate the detection of AgNPs using a Tecnai Spirit transmission electron microscope (FEI Company; Hillsboro, OR, USA).

\section{ROS detection}

SUM159 and iMEC cells were plated on 8-well coverslipbottom chamber slides (EMD Millipore, Burlington, MA, USA) at a density of 30,000 cells per well in $400 \mu \mathrm{L}$ of complete medium. Cells were allowed to recover for $48 \mathrm{~h}$ and then were exposed to $\mathrm{AgNPs}$ or $\mathrm{Ag}^{+}$with or without PEG-Catalase (100 units/mL) for $24 \mathrm{~h}$ at $37{ }^{\circ} \mathrm{C}$. Medium was removed and cells were washed with PBS, and incubated with $10 \mu \mathrm{M}$ 2,7'-dichlorodihydrofluorescein diacetate $\left(\mathrm{H}_{2}\right.$ DCF-DA) (Invitrogen) or PeroxyOrange-1 (PO1) (Tocris) for $30 \mathrm{~min}$ at $37^{\circ} \mathrm{C}$. Fluorescence was visualized using an Olympus FV1200 spectral laser scanning confocal microscope.

\section{ICP-MS}

A freshly prepared suspension of AgNPs dispersed in PBS at $5 \mathrm{mg} / \mathrm{mL}$ was transferred to a $5000 \mathrm{MWCO}$ VivaSpin column (Viva products, Littleton, MA) and centrifuged at $3000 \times \mathrm{g}$ for $15 \mathrm{~min}$. The same suspension of AgNPs was stored at $4{ }^{\circ} \mathrm{C}$ for 1 week and processed as described. The flow through, containing any soluble silver, was collected and stored at $4{ }^{\circ} \mathrm{C}$. Triplicate, $50 \mu \mathrm{L}$ samples were then digested with $1 \mathrm{~mL}$ of concentrated $\mathrm{HNO}_{3}, 2 \mathrm{~mL}$ of $30 \% \mathrm{H}_{2} \mathrm{O}_{2}$ and $7 \mathrm{~mL}$ of distilled-deionized water using a microwave-assisted digestion system (Ethos UP, Milestone, Sorisole, Italy). The digested samples were diluted to a final acid concentration of $2 \% \mathrm{v} / \mathrm{v}$ before Ag determination by inductively coupled plasma mass spectrometry (ICP-MS). Trace metal grade $\mathrm{HNO}_{3}$ (Fisher, Pittsburgh, PA, USA), and distilled-deionized water (18 $\mathrm{M} \Omega \mathrm{cm}$, Milli- $\mathrm{Q}^{\circledR}$, Millipore) were used to digest samples and prepare all solutions. Low trace metals hydrogen peroxide (Veritas, Columbus, OH, USA) was also used for sample digestion. Standard reference solutions used for calibration were prepared in $2 \% \mathrm{v} / \mathrm{v}$ $\mathrm{HNO}_{3}$ from a $10 \mathrm{mg} / \mathrm{L} \mathrm{Ag}$ stock (High-Purity Standards, Charleston, SC, USA). A tandem ICP-MS (8800 ICP-MS, Agilent Technologies, Tokyo, Japan), equipped with a SPS 4 automatic sampler, a Scott-type double pass spray chamber operated at $2{ }^{\circ} \mathrm{C}$, and a glass concentric nebulizer were used in all determinations. Helium gas $(>=99.999 \%$ purity, Airgas) was used in the ICP-MS's collision/reaction cell to minimize potential spectral interferences, while monitoring the ${ }^{109} \mathrm{Ag}$ isotope in single quadrupole mode. Other relevant instrument operating conditions such as radio frequency applied power, sampling depth, carrier gas flow rate, and reaction gas flow rate were $1550 \mathrm{~W}, 10.0 \mathrm{~mm}, 1.05 \mathrm{~L} / \mathrm{min}$, and $4.0 \mathrm{~mL} /$ min, respectively.

\section{Apoptosis/necrosis analysis}

SUM159 and iMEC cells were plated at a density of 500,000 cells per well in a 6 well plate and allowed to adhere overnight. Cells were then treated with AgNPs, $\mathrm{Ag}^{+}$or vehicle. After $24 \mathrm{~h}$ cells were washed twice with PBS, trypsinized, and resuspended in their respective media. Cells were then pelleted by centrifugation at $320 \times \mathrm{g}$ for $5 \mathrm{~min}$. Cells were washed with PBS and pelleted again by centrifugation at $320 \times \mathrm{g}$ for $5 \mathrm{~min}$. FITCconjugated Annexin $\mathrm{V}$ and ethidium homodimer III staining was performed per the manufacturer's instructions (Biotium, Fremont, CA). Labeled cells were analyzed on a FACS Canto II Analyzer (BD Biosciences). Analysis of the data was performed using FCS express version 7 (De Novo Software, Glendale, CA, USA). Unstained samples were included to control for any potential interference of AgNPs with flow cytometry. There was no detectable change in background fluorescence in the unstained samples, indicating that AgNPs did not interfere with the assay [Additional file 1: Fig. S1B].

\section{Statistical analysis}

Analysis was performed using GraphPad Prism 9.0 software as described in the figure legends. The number of experimental and biological replicates used for each experiment is included in the figure legends.

\section{Results}

Contamination of AgNP suspensions with as little as $1 \%$ $\mathrm{Ag}^{+}$by mass can mask AgNP-specific cytotoxicity

We purchased $25 \mathrm{~nm}$, PVP coated, AgNPs from nanoComposix Inc. (Lot \#ALJ0052-MGM2463A) and stored them as a lyophilized powder in the dark at $4{ }^{\circ} \mathrm{C}$. Prior to use in cell culture experiments, we characterized the hydrodynamic diameter of AgNPs after hydration in PBS or dilution in cell culture media using nanoparticle 
A.
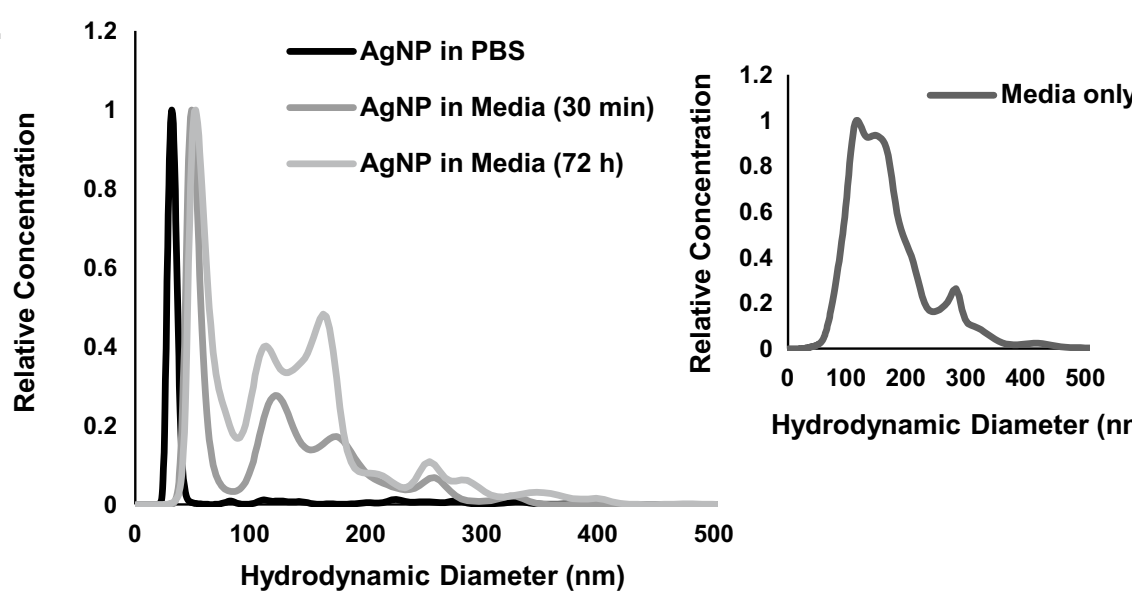

Hydrodynamic Diameter $(\mathrm{nm})$

B.

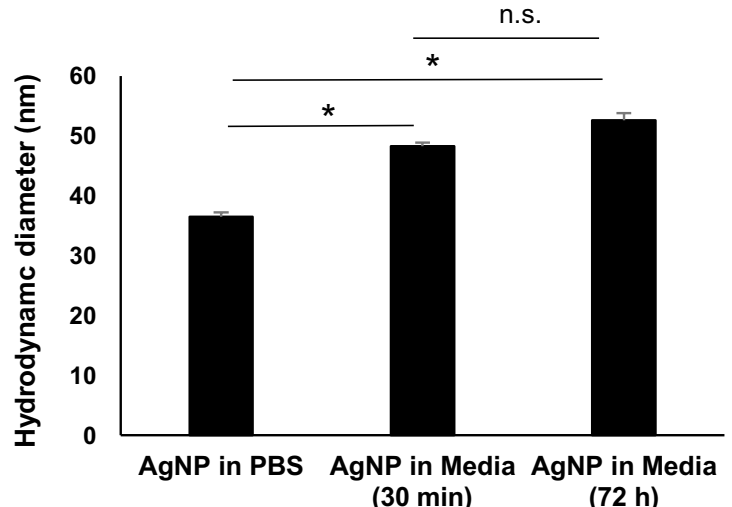

C.

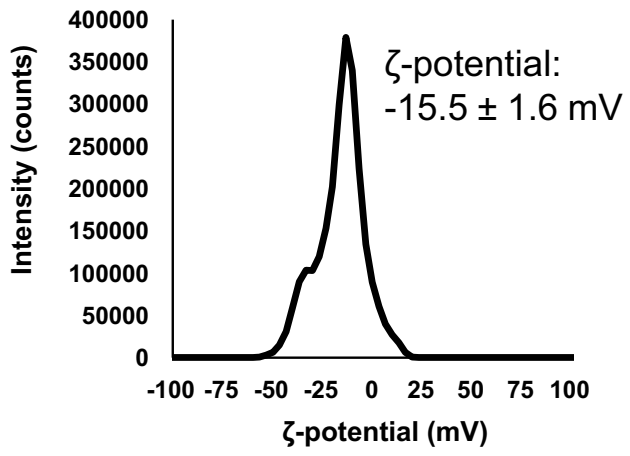

D.

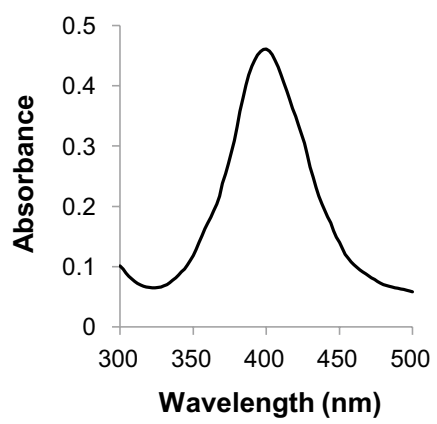

E.

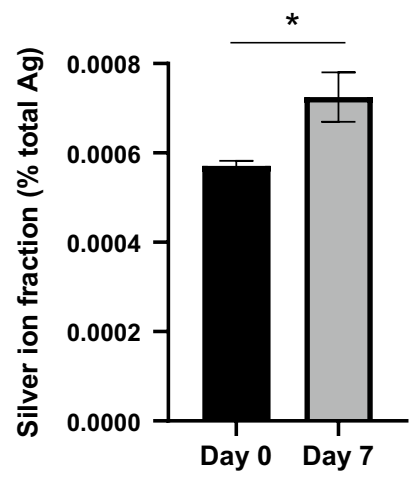

Fig. 1 No evidence of AgNP aggregation and minimal release of $\mathrm{Ag}^{+}$were detected following storage of AgNPs. A Nanoparticle tracking analysis was used to determine the hydrodynamic diameter of AgNPs in PBS, 30 min after dilution in cell culture media, and $72 \mathrm{~h}$ after dilution in cell culture media. The inset to the right shows the size distribution of particulate material in the media itself. B The peak from the hydrodynamic diameter for AgNPs measured in (A) was identified and the median values of five measurements per condition \pm standard deviation are shown. C The $\zeta$-potential distribution of AgNPs dispersed PBS at pH 7.4 after 100X dilution in water is shown. D The UV/visible light absorbance spectrum of AgNPs (arbitrary units (a.u.) is shown. E The fraction of $\mathrm{Ag}^{+}$relative to total silver mass in a freshly prepared dispersion of AgNPs or following storage for 7 days is show. Statistical analysis was performed by Student T-test. Significant differences are indicated $\left({ }^{*} p<0.05\right)$; n.s. not significant

tracking analysis (NTA) (Fig. 1A, B). A single sharp peak corresponding to AgNPs was observed for size ranges under $100 \mathrm{~nm}$. Additional peaks in the size range greater than $100 \mathrm{~nm}$ were attributable to the media, possibly indicating the presence of exosomes or protein aggregates. The hydrodynamic diameter measured at the AgNP peak increased from $36.5 \pm 0.7 \mathrm{~nm}$ in PBS to $48.3 \pm 0.6$ after incubation in cell culture media for 
$30 \mathrm{~min}$, likely due to formation of a protein corona. After $72 \mathrm{~h}$ in media, a non-significant $(p>0.05)$ size increased to $52.6 \pm 1.2$ was detected and there was no evidence of large aggregate formation or sedimentation. The $\zeta$-potential in PBS at pH 7.4 was $-15.5 \pm 1.6 \mathrm{mV}$ (Fig. 1C), and the plasmon resonance peak was $402 \mathrm{~nm}$, which is typical for $25 \mathrm{~nm}$, spherical AgNPs (Fig. 1D). We quantified the amount of soluble silver $\left(\mathrm{Ag}^{+}\right)$present in the AgNP suspension by separating the solid and soluble fractions using a size exclusion, spin column. The silver content of the filtered solution was quantified by ICP-MS and the mass of silver in the filtrate was compared to the total mass of silver in the initial suspension of AgNPs. As shown in (Fig. 1D), a freshly prepared suspension of AgNPs contained only $0.000571 \% \mathrm{Ag}^{+}$by mass. Following 7 days of storage, there was a slight increase in the $\mathrm{Ag}^{+}$fraction to $0.000725 \%$.

Next, we asked if this fraction of $\mathrm{Ag}^{+}$was sufficient to drive cytotoxic responses to AgNPs in cells with high or low sensitivity to AgNPs. Previously, we found that AgNPs were lethal to a subset of breast cancer cell lines, including SUM159 cells, at doses that had little effect on the viability of various models of normal breast epithelia, including iMEC cells [11]. Therefore, we used SUM159 cells as a model for an AgNP sensitive cell line, and iMEC cells as a model for an AgNP insensitive cell line. Both cell types were exposed to increasing doses of $\mathrm{AgNPs}$ or $\mathrm{Ag}^{+}$for $72 \mathrm{~h}$. Because aging of AgNPs or $\mathrm{Ag}^{+}$ in cell culture media can reduce their cytotoxicity [8], we minimized any effects due to interactions with media components by using dilutions of $\mathrm{AgNPs}$ and $\mathrm{Ag}^{+}$in cell culture media within $30 \mathrm{~min}$ of preparation. Viability was assessed by MTT assay, and the half-maximal inhibitory concentration $\left(\mathrm{IC}_{50}\right)$ of AgNPs or $\mathrm{Ag}^{+}$in relation to viability was calculated. Based upon differences in $\mathrm{IC}_{50}$, we observed SUM159 cells were approximately 6.5-fold more sensitive to AgNP exposure compared to iMEC cells ( $\mathrm{IC}_{50}$ of $15.1 \mathrm{vs} 97.9 \mu \mathrm{g} / \mathrm{mL}$ respectively) (Fig. 2A). In contrast, SUM159 cells were approximately 5.6-fold less sensitive to $\mathrm{Ag}^{+}$compared to iMEC cells $\left(\mathrm{IC}_{50}\right.$ of 1.03 vs $5.8 \mu \mathrm{g} / \mathrm{mL}$ respectively) (Fig. $2 \mathrm{~B}$ ). We verified these differences in sensitivity to AgNPs and $\mathrm{Ag}^{+}$by evaluating clonogenic growth after AgNP or $\mathrm{Ag}^{+}$exposure. In agreement with the results from the MTT assay, clonogenic assays showed that AgNPs were significantly more cytotoxic towards SUM159 cells compared to iMEC cells (Fig. 2C), while $\mathrm{Ag}^{+}$treatment was significantly more cytotoxic towards iMEC cells compared to SUM159 cells (Fig. 2D). Based upon the fraction of $\mathrm{Ag}^{+}$present in the AgNP suspension as determined by ICP-MS (Fig. 1D), a dose of $100 \mu \mathrm{g} / \mathrm{ml}$ of intact AgNPs at most would contain $0.000725 \mu \mathrm{g} / \mathrm{ml}$ of $\mathrm{Ag}^{+}$. This concentration of $\mathrm{Ag}^{+}$ did not decrease the viability of either cell line, indicating that the cytotoxicity induced by AgNPs was not due to the small amount of $\mathrm{Ag}^{+}$remaining in the suspension. Because SUM159 cells were significantly more sensitive to AgNPs compared to iMEC cells but were less sensitive to $\mathrm{Ag}^{+}$, these data suggested the cytotoxicity induced by intact AgNPs was distinct from that of $\mathrm{Ag}^{+}$.

To determine what fraction of $\mathrm{Ag}^{+}$present in a suspension of AgNPs could affect the overall cytotoxicity profile, we exposed cells to increasing concentrations of AgNP and $\mathrm{Ag}^{+}$mixtures containing 99-70\% intact AgNPs with $1-30 \% \mathrm{Ag}^{+}$by total silver mass (Fig. 3A-D). We then calculated the $\mathrm{IC}_{50}$ for each mixture based upon total silver concentration (Fig. 3E). As noted above, iMEC cells were relatively insensitive to intact AgNPs, but highly sensitive to $\mathrm{Ag}^{+}$. In agreement with this, there was a shift in the $\mathrm{IC}_{50}$ in iMEC cells for $100 \%$ AgNPs from $97.9 \mu \mathrm{g} / \mathrm{mL}$ (Fig. $2 \mathrm{~A}$ ) to $25.6 \mu \mathrm{g} / \mathrm{mL}$ for a mixture of $99 \%$ AgNPs $/ 1 \%$ $\mathrm{Ag}^{+}$(Fig. 3A, E). As the percentage of $\mathrm{Ag}^{+}$increased, the $\mathrm{IC}_{50}$ in iMEC cells dropped to $15.1 \mu \mathrm{g} / \mathrm{mL}$ at $95 \%$ $\mathrm{AgNP} / 5 \% \mathrm{Ag}^{+}$(Fig. 3B, E), $6.3 \mu \mathrm{g} / \mathrm{mL}$ at $90 \% \mathrm{AgNP} / 10 \%$ $\mathrm{Ag}^{+}$(Fig. 3C, E), and $4.8 \mu \mathrm{g} / \mathrm{mL}$ at $70 \% \mathrm{AgNP} / 30 \%$ $\mathrm{Ag}^{+}$(Fig. 3D, E). The opposite trend was observed for SUM159 cells, which were sensitive to intact AgNPs but comparatively insensitive to $\mathrm{Ag}^{+}$(Fig. 2A, B). There was a small but not statistically significant $(p>0.05)$ increase in $\mathrm{IC}_{50}$ of a $99 \% \mathrm{AgNP} / 1 \% \mathrm{Ag}^{+}$compared to $100 \% \mathrm{AgNP}$ (28.2 vs $15.1 \mu \mathrm{g} / \mathrm{mL}$ respectively; Figs. $2 \mathrm{~A}$ and $3 \mathrm{~A}, \mathrm{E})$. The $\mathrm{IC}_{50}$ increased to $40.8 \mu \mathrm{g} / \mathrm{mL}$ for $95 \% \mathrm{AgNP} / 5 \% \mathrm{Ag}^{+}$ $\left(40.78 \mu \mathrm{g} / \mathrm{mL}\right.$; Fig. 3B, E). The $\mathrm{IC}_{50}$ for the $90 \% \mathrm{AgNP} / 10 \%$ $\mathrm{Ag}^{+}(33.9 \mu \mathrm{g} / \mathrm{mL}$; Fig. 3C, E) also was greater than that of the 100\% AgNP treatment. Only for the $70 \% \mathrm{AgNP} / 30 \%$ $\mathrm{Ag}^{+}$treatment of SUM159 cells did the $\mathrm{IC}_{50}(12.9 \mu \mathrm{g} / \mathrm{mL})$ fall below that of the 100\% AgNP treatment (Fig. 3D, E). As shown in Fig. 3E, as little as a $1 \% \mathrm{Ag}^{+}$mass fraction in an AgNP suspension narrowed the difference in sensitivity of iMEC and SUM159 cells compared to exposure to intact AgNPs free from $\mathrm{Ag}^{+}$. Mixtures of AgNPs containing $5 \%$ or greater mass fractions of $\mathrm{Ag}^{+}$were significantly less cytotoxic to SUM159 than they were to iMEC cells, which is the opposite of what was observed for AgNPs in the absence of $\mathrm{Ag}^{+}$. These data show that depending on cell line and relative sensitivity to intact AgNPs versus $\mathrm{Ag}^{+}$, the fraction of $\mathrm{Ag}^{+}$present in an AgNP suspension can mask or even reverse any inherent differences between the cytotoxic responses of cells to intact AgNPs.

\section{Both AgNP and $\mathrm{Ag}^{+}$increase intracellular $\mathrm{H}_{2} \mathrm{O}_{2}$, but only $\mathrm{Ag}^{+}$cytotoxicity is dependent upon $\mathrm{H}_{2} \mathrm{O}_{2}$}

Having established that AgNPs and $\mathrm{Ag}^{+}$exhibit distinct cytotoxic responses, we looked for mechanistic differences that could account for this. First, we examined total ROS in SUM159 and iMEC cells after 24 h exposure to $\mathrm{AgNPs}$ or $\mathrm{Ag}^{+}$by quantifying changes in fluorescence 
A.

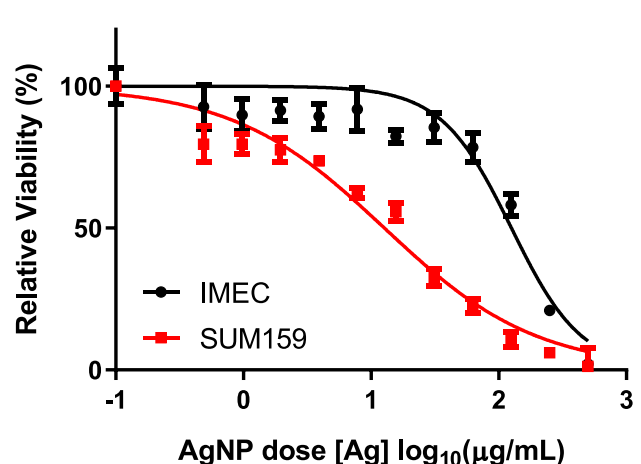

B.

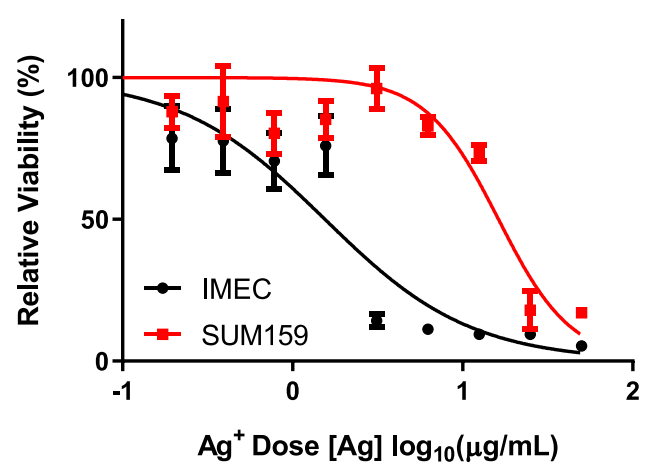

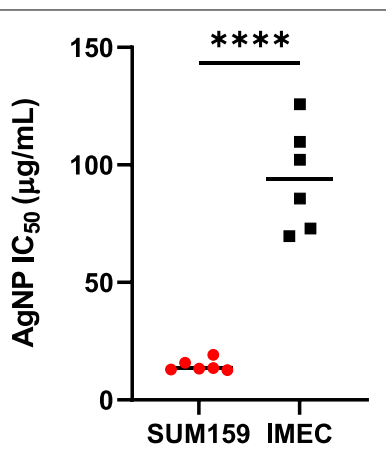

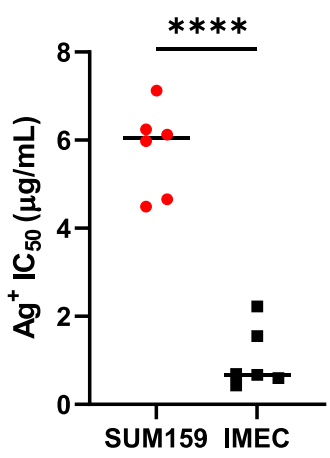

C.

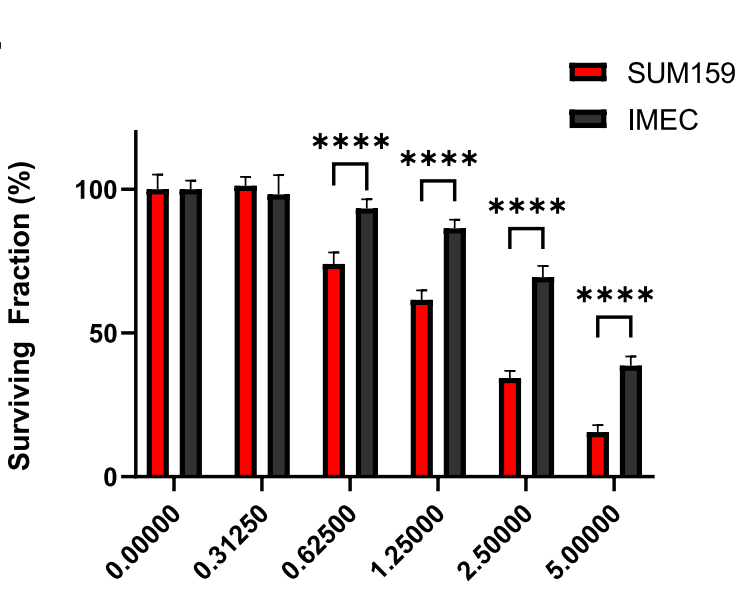

AgNP Dose $[\mathrm{Ag}](\mu \mathrm{g} / \mathrm{mL})$
D.

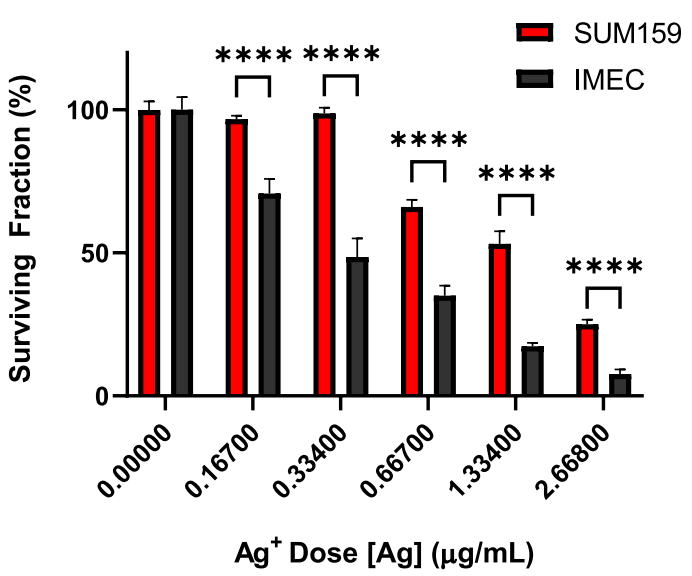

Fig. 2 Sensitivity to AgNPs is independent from sensitivity to silver ion. Representative dose response curves and IC ${ }_{50}$ following $72 \mathrm{~h} \mathbf{A}$ AgNP or $\mathbf{B}$ $\mathrm{Ag}^{+}$exposure. Cell viability following $72 \mathrm{~h}$ AgNP or $\mathrm{Ag}^{+}$exposure was quantified by MTT assay and IC50 was determined using GraphPad Prism. Data used to calculate $\mathrm{IC}_{50} \mathrm{~s}$ were obtained from 6 technical replicates per dose and 3 independent experiments (biological replicates). Statistical analysis was performed by two-was ANOVA and post-hoc Tukey Test. Significant differences are indicated $\left.{ }^{* * * *} p<0.0001\right)$. Long-term proliferative potential was assessed via clonogenic assay following $24 \mathrm{~h} \mathbf{C ~ A g N P}$ or $\mathbf{D ~ A g}{ }^{+}$exposure. The data are presented as relative surviving fraction based upon clonogenic growth normalized to the plating efficiency. Statistical analysis was performed by two-way ANOVA followed by post-hoc Tukey Test. Statistical differences are indicated $\left({ }^{* * *} p<0.0001\right)$

intensity of $\mathrm{CM}-\mathrm{H}_{2} \mathrm{DCF}-\mathrm{DA}$. Treatment of cells with PEG-catalase, a cell permeable antioxidant that enzymatically catalyzes the reduction of $\mathrm{H}_{2} \mathrm{O}_{2}$ to water and $\mathrm{O}_{2}$, was used as a control to determine the contribution of $\mathrm{H}_{2} \mathrm{O}_{2}$ to $\mathrm{CM}-\mathrm{H}_{2}$ DCF-DA fluorescence signal. Unstained samples treated with AgNPs were imaged in parallel 
A.

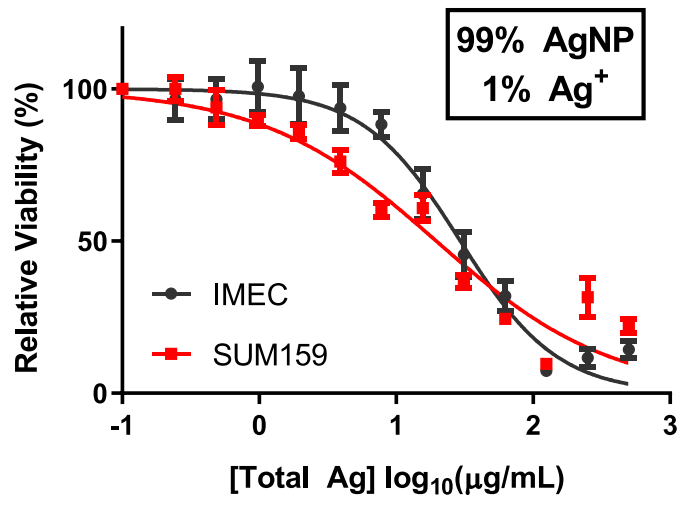

C.

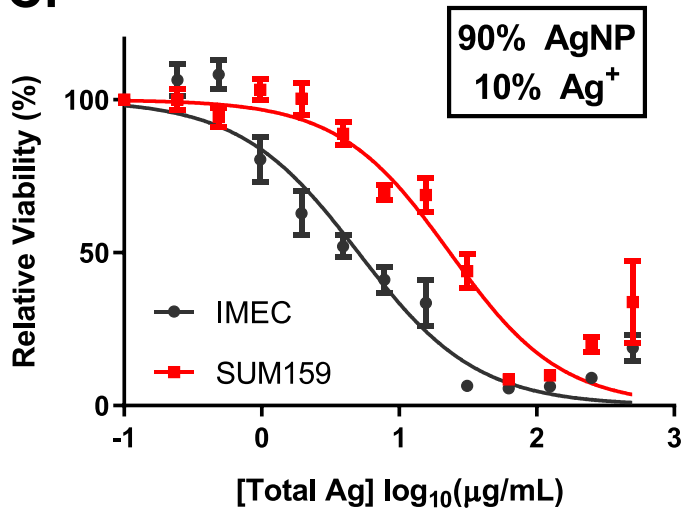

E.

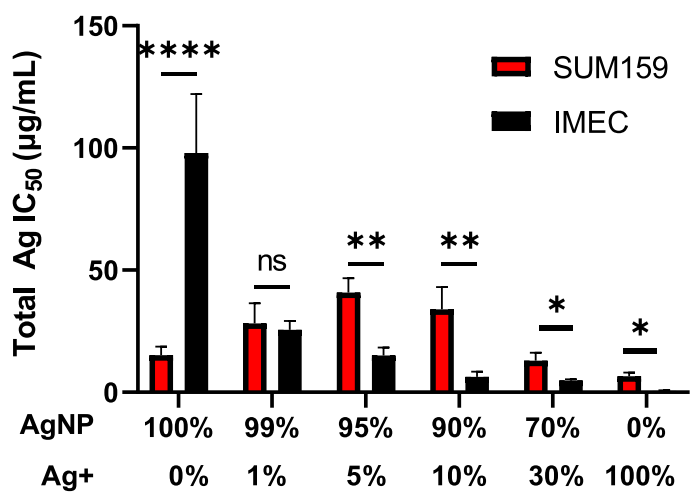

B.

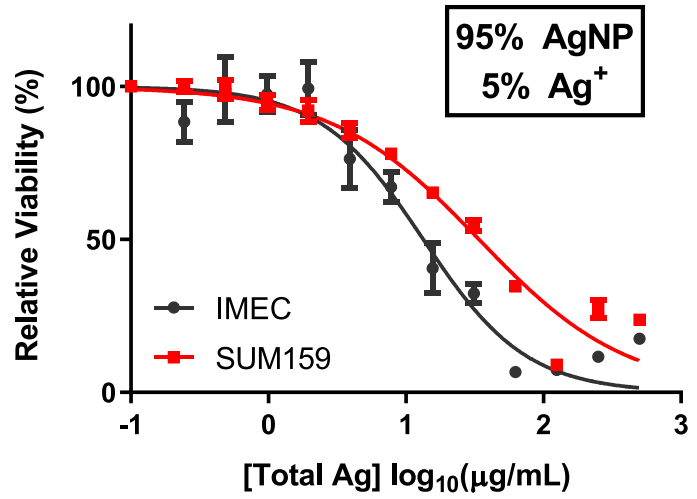

D.

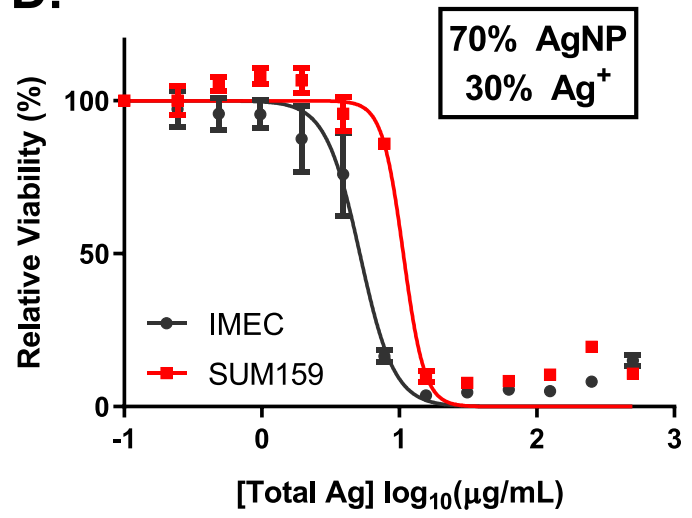

Fig. 3 Presence of $\mathrm{Ag}^{+}$in AgNP dispersions masks differences in sensitivity of cell lines to AgNPs. Representative dose response curves following $72 \mathrm{~h} \mathrm{AgNP}-\mathrm{Ag}^{+}$exposure in the following proportions A 99\% AgNP/1\% Ag ${ }^{+}, \mathbf{B} 95 \% \mathrm{AgNP} / 5 \% \mathrm{Ag}^{+}, \mathbf{C} 90 \% \mathrm{AgNP} / 10 \% \mathrm{Ag}{ }^{+}, \mathbf{D} 70 \% \mathrm{AgNP} / 30 \% \mathrm{Ag}{ }^{+}$. Cell viability following AgNP-Ag ${ }^{+}$exposure was quantified by MTT assay. E IC 50 was determined using GraphPad Prism. Data used to calculate IC50s were obtained from 6 technical replicates per dose and 2-3 independent experiments. Statistical analysis was performed by two-way ANOVA followed by post-hoc Sidaks test. Significant differences are indicated $\left({ }^{*} p<0.05 ;{ }^{* *} p<0.01 ;{ }^{* * *} p<0.0001\right)$

to ensure AgNPs did not affect background fluorescence (Additional file 1: Fig. S2). There was a significant $(p<0.01)$ increase in ROS in both cell lines following both $\mathrm{Ag}^{+}$and AgNP treatment, and this increase was blocked by PEG-catalase (Fig. 4A, B). Following exposure to $\mathrm{Ag}^{+}$, significantly more ROS was generated by iMEC cells compared to SUM159 cells, which is in agreement with their relative sensitivity to $\mathrm{Ag}^{+}$. CM- $\mathrm{H}_{2} \mathrm{DCF}-\mathrm{DA}$ fluorescence 


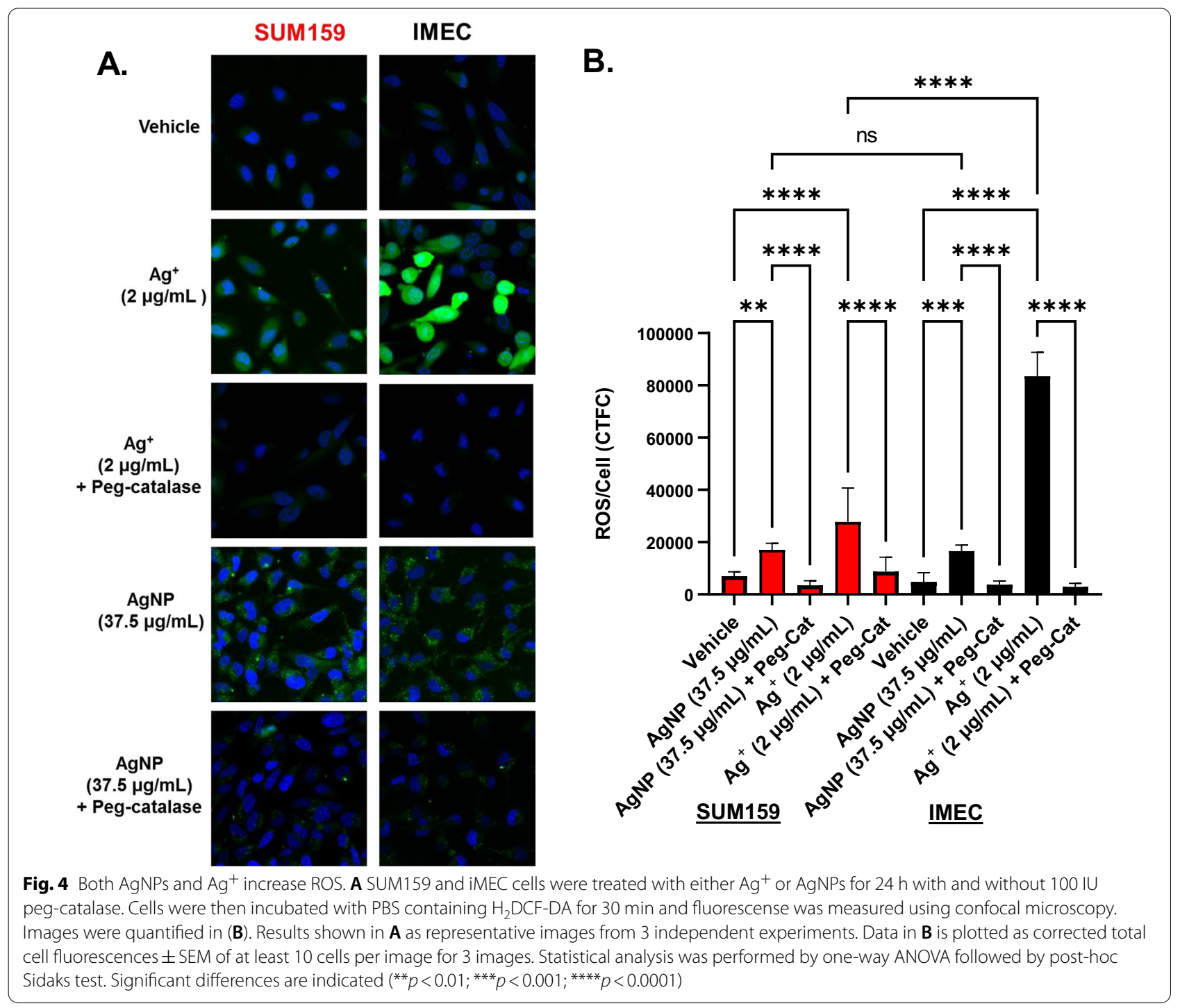

after $\mathrm{Ag}^{+}$exposure was observed throughout the entire volume of both cell lines. In contrast, similar increases in ROS were observed for AgNP treated iMEC and SUM159 cells, and the $\mathrm{CM}-\mathrm{H}_{2} \mathrm{DCF}-\mathrm{DA}$ fluorescence after AgNP exposure was punctate and only observed in the cytoplasm. TEM images of AgNPs in iMEC and SUM159 cells show intact nanoparticles in membrane bound vesicles consistent with endosomes (Additional file 1: Fig. S3), indicating that AgNP-induced increases in ROS may be localized to these compartments.

Of the major types of ROS, $\mathrm{H}_{2} \mathrm{O}_{2}$ has the longest biological half-life and is capable of diffusing through cell compartments via aquaporins present in membranes [36]. $\mathrm{H}_{2} \mathrm{O}_{2}$ is known to be a major contributor to the toxicity of $\mathrm{Ag}^{+}[23,26]$ and other redox active metals like iron [37]. We therefore focused on the contribution of $\mathrm{H}_{2} \mathrm{O}_{2}$ to AgNP and $\mathrm{Ag}^{+}$cytotoxicity. PeroxyOrange- 1 (PO1) is a specific probe for $\mathrm{H}_{2} \mathrm{O}_{2}$ [38]. Quantification of PO1 staining in AgNP and $\mathrm{Ag}^{+}$treated iMEC or SUM159 cells produced similar results to those observed for CMH2DCF-DA (Additional file 1: Fig. S4). Because AgNP and $\mathrm{Ag}^{+}$treatment increased intracellular $\mathrm{H}_{2} \mathrm{O}_{2}$, we asked if this contributed to cell death caused by AgNP or $\mathrm{Ag}^{+}$exposure. SUM159 and iMEC cells were co-treated with PEG-catalase and AgNPs or $\mathrm{Ag}^{+}$for $24 \mathrm{~h}$ and cell viability was assessed by MTT assay. PEG-catalase treatment did not affect AgNP-mediated cytotoxicity in SUM159 (Fig. 5A) or iMEC cells (Fig. 5B), and there was no significant change in the $\mathrm{IC}_{50}$ of AgNP treatment for either cell line (Fig. 5C). However, PEG-catalase decreased the cytotoxicity of $\mathrm{Ag}^{+}$in both SUM159 (Fig. 5D) and iMEC cells (Fig. 5E). The $\mathrm{IC}_{50}$ of $\mathrm{Ag}^{+}$ 


\begin{abstract}
(See figure on next page.)
Fig. 5 Reduction of hydrogen peroxide through PEG-catalase attenuates $\mathrm{Ag}^{+}$but not AgNP mediated cell death. A SUM159 or B iMEC cells were exposed to increasing doses of AgNPs with or without 100 units/mL of PEG-catalase. Cell viability following $24 \mathrm{~h}$ AgNP exposure was quantified by MTT assay. $C I_{50}$ was calculated using GraphPad Prism. Data used to calculate IC $C_{50}$ 's were obtained from 6 technical replicates per dose and 3 independent experiments (biological replicates). D SUM159 or E iMEC cells were exposed to increasing doses of $\mathrm{Ag}^{+}$with or without 100 units/ $\mathrm{mL}$ of PEG-catalase. Cell viability following $24 \mathrm{~h} \mathrm{Ag}{ }^{+}$exposure was quantified by MTT assay. $\mathbf{F} I C_{50}$ was calculated using GraphPad Prism. Data used to calculate $I_{50}$ 's were obtained from 6 technical replicates per dose and 3 independent experiments (biological replicates). Statistical analysis in $\mathbf{C}$ and $\mathbf{F}$ was performed by students T-Test. Statistical differences are indicated $\left({ }^{* *} p<0.01\right.$; $\left.{ }^{* * *} p<0.0001\right)$. G, $\mathbf{H}$ Long term proliferative potential was assessed via clonogenic assay following $24 \mathrm{~h}$ AgNP exposure in the presence of 100 units $/ \mathrm{mL}$ of PEG-catalase in G SUM159 and $\mathbf{H}$ iMEC cells. I, J Long-term proliferative potential was assessed via clonogenic assay following $24 \mathrm{~h} \mathrm{Ag}+$ exposure in the presence of $100 \mathrm{units} / \mathrm{mL}$ of peg-catalase in I SUM159 and $\mathbf{J}$ iMEC cells. Data in G-J are presented as relative surviving fraction based upon clonogenic growth normalized to plating efficiency. Statistical analysis was performed by one-way ANOVA followed by post-hoc Tukey Test. Statistical differences are indicated $\left({ }^{*} p<0.05\right)$
\end{abstract}

exposure to SUM159 cells increased twofold in the presence of PEG-catalase, and there was a threefold increase in $\mathrm{IC}_{50}$ for $\mathrm{Ag}^{+}$exposure to iMEC cells in the presence of PEG-catalase (Fig. 5F). Clonogenic growth of SUM159 and iMEC cells after AgNP or $\mathrm{Ag}^{+}$exposure with or without PEG-catalase also was evaluated. In agreement with results from the MTT assay, PEG-catalase did not alter clonogenic growth of both iMEC and SUM159 cells following AgNP exposure (Fig. 5G, H), but did protect both cell lines from $\mathrm{Ag}^{+}$(Fig. 5I, J).

We further evaluated the effect of catalase on sensitivity to AgNPs and $\mathrm{Ag}^{+}$using genetically modified SUM159 cells engineered to express doxycycline-inducible catalase (SUM159 $9^{\text {cat }}$ ). Increased expression of catalase after doxycycline treatment was verified by immunoblotting (Fig. 6A), and reduction of baseline $\mathrm{H}_{2} \mathrm{O}_{2}$ level was verified by PO1 staining (Fig. $6 \mathrm{~B}$ ). Similarly to what was observed with the addition of PEG-catalase, over-expression of catalase did not affect AgNP-mediated cytotoxicity (Fig. 6C) but was protective against $\mathrm{Ag}^{+}$(Fig. 6D). There was no significant change in $\mathrm{IC}_{50}$ of AgNP treatment (Fig. 6E), but catalase overexpression increased the $\mathrm{IC}_{50}$ of $\mathrm{Ag}^{+}$(Fig. 6F). Clonogenic growth assays confirmed that catalase over-expression did not protect SUM159 $9^{\text {cat }}$ cells from AgNPs (Fig. 6G), but was protective against $\mathrm{Ag}^{+}$(Fig. 6H). Taken together, these data indicate that production of $\mathrm{H}_{2} \mathrm{O}_{2}$ plays a causal role in $\mathrm{Ag}^{+}$mediated cytotoxicity but is not crucial for AgNPmediated cytotoxicity.

\section{AgNPs but not $\mathrm{Ag}^{+}$induce lipid peroxidation}

Because $\mathrm{H}_{2} \mathrm{O}_{2}$ did not contribute to the cytotoxicity of AgNPs, we asked if lipid peroxides could play a role. We used Liperfluo, a fluorescent probe that is specific for detecting lipid peroxides [39], to quantify changes in lipid peroxidation following $\mathrm{AgNP}$ or $\mathrm{Ag}^{+}$exposure. We observed a significant $(p<0.05)$ increase in lipid peroxidation in AgNP treated SUM159 cells compared to vehicle, but there was no change in lipid peroxides in similarly treated iMEC cells (Fig. 7A), which is consistent with their relative sensitivities to AgNPs. No change in lipid peroxidation was observed in SUM159 and iMEC cells following $\mathrm{Ag}^{+}$treatment (Fig. 7B). 4-Hydroxynonenal (4-HNE) is a toxic endproduct of lipid peroxide decomposition. 4-HNE readily forms protein adducts as both Michael addition products and Schiff bases. We observed a dose dependent increase in histidine adducts of 4-HNE in SUM159 cells exposed to AgNPs, but little change was observed in iMEC cells (Fig. 7C). Consistent with the lack of lipid peroxidation, there was no increase in histidine adducts of 4-HNE following $\mathrm{Ag}^{+}$exposure in either SUM159 (Fig. 7D) or iMEC cells (Fig. 7E). These data show that intact AgNPs cause lipid peroxidation, which correlates with overall sensitivity to AgNP exposure. In contrast, $\mathrm{Ag}^{+}$exposure did not cause lipid peroxidation regardless of relative sensitivity of cell lines to $\mathrm{Ag}^{+}$.

\section{Protein oxidation and aggregation due to AgNPs or $\mathrm{Ag}^{+}$ exposure differs between cell lines and correlates with their relative sensitivity to $\mathrm{AgNPs}$ or $\mathrm{Ag}^{+}$}

Both $\mathrm{H}_{2} \mathrm{O}_{2}$ and lipid peroxides can spread direct effects of AgNPs or $\mathrm{Ag}^{+}$and cause damage including oxidation of thiols in proteins leading to generation of sulfenic acids [40]. Thiol oxidation and formation of 4-HNE adducts can induce protein misfolding and aggregation [41, 42]. Because iMEC and SUM159 cells exhibited opposite relative sensitivities to AgNPs and $\mathrm{Ag}^{+}$, we wondered if AgNPs and $\mathrm{Ag}^{+}$would also induce distinct patterns of protein oxidation and aggregation that would correlate with relative sensitivity of the cells to these toxicants. To assess protein oxidation, we used DCP-NEt2-C, a fluorescent probe that is specific for imaging mitochondrial protein sulfenylation [35]. In agreement with their relative sensitivity to AgNPs, there was a significant, dose dependent increase in protein oxidation in SUM159 cells following AgNP exposure (Fig. 8A). For iMEC cells, there was a small decrease in protein oxidation (Fig. 8A). As expected based upon their relative sensitivity, the opposite pattern was observed following exposure of cells 


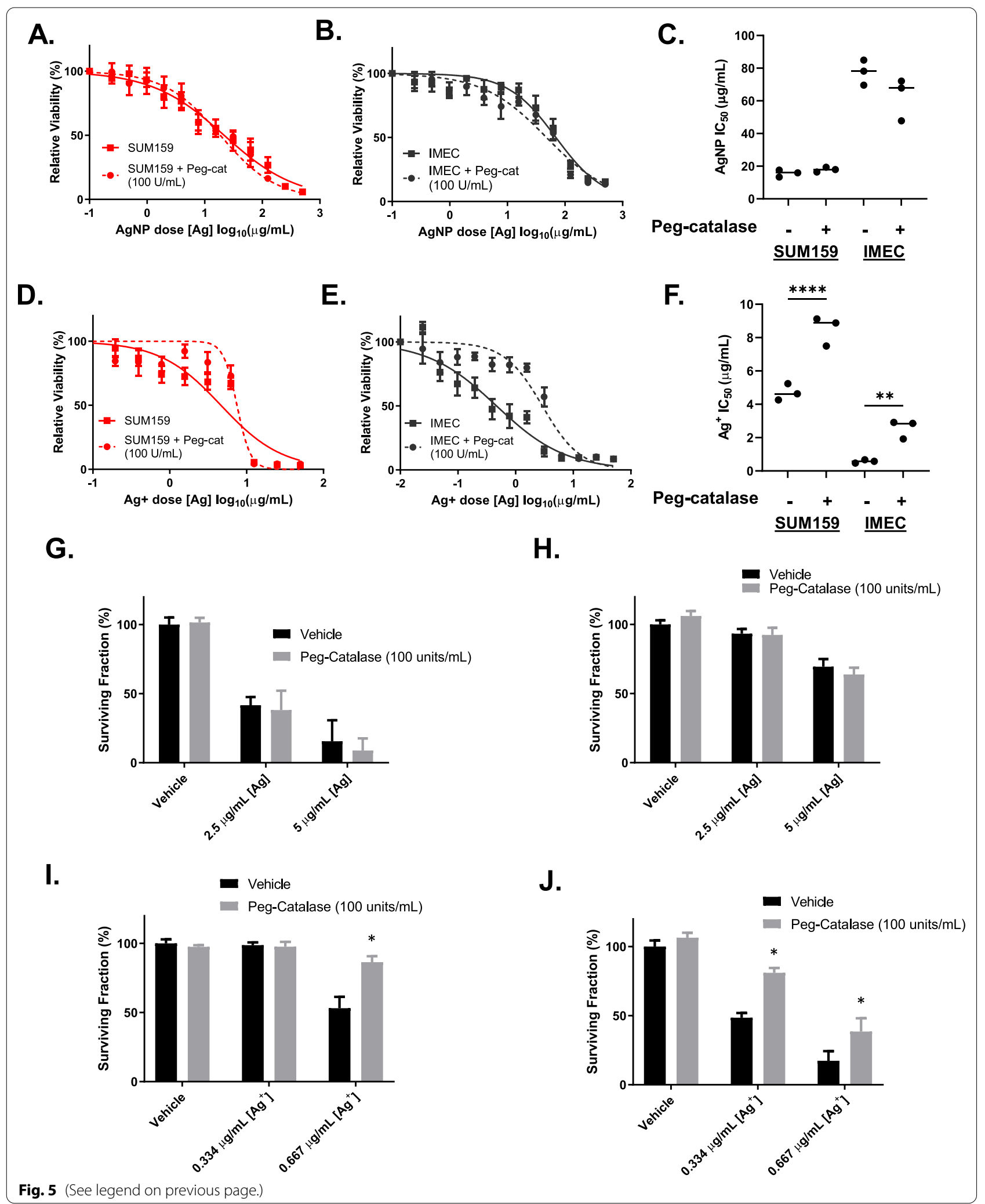


(See figure on next page.)

Fig. 6 Reduction of hydrogen peroxide by over-expression of catalase catalase attenuates $\mathrm{Ag}^{+}$but not AgNP mediated cell death. A Catalase expression was determined by western blot in parental SUM159, SUM159Cat (-)Dox, and SUM159 Cat ( ${ }^{+}$)Dox cells. B SUM159 Cat cells cultured with or without doxycycline were incubated with PBS containing PO1 and fluorescence was measured using confocal microscopy. C, D SUM159 Cat cells cultured with or without doxycycline were exposed to increasing concentrations of $\mathbf{C ~ A g N P s ~ o r ~} \mathbf{E ~ A g}{ }^{+}$for $72 \mathrm{~h}$. Cell viability was quantified by MTT assay. IC $C_{50}$ 's were calculated for $\mathbf{D}$ AgNPs or $\mathbf{F} \mathrm{Ag}^{+}$using GraphPad prism. Data used to calculate IC50s were obtained from 6 technical replicates and 3 independent experiments (biological replicates). Statistical analysis was performed by Students T-test. Statistical differences are indicated $\left(^{*} p<0.05\right)$. G, H Long-term proliferative potential was assessed via clonogenic assay after 24 h exposure to $\mathbf{G}$ AgNPs or $\mathbf{H ~ A g}{ }^{+}$in SUM159 Cat cells cultured with or without doxycycline. Data are presented as relative surviving fraction based upon clonogenic growth normalized to plating efficiency. Statistical analysis was performed by two-way ANOVA followed by post-hoc Tukey Test. Statistical differences are indicated ( $\left.{ }^{*} p<0.05\right)$

to $\mathrm{Ag}^{+}$. There was no change in protein oxidation in SUM159 cells exposed to $\mathrm{Ag}^{+}$at either dose, but there was nearly a twofold increase in protein oxidation in iMEC cells exposed to a $2 \mu \mathrm{g} / \mathrm{ml}$ dose of $\mathrm{Ag}^{+}$(Fig. 8B). Similarly, imaging and quantification of protein aggregation using proteostat, a dye that fluoresces after intercalation into hydrophobic pockets formed by misfolded or aggregated proteins, also correlated with differences in sensitivity of cell lines to AgNPs or $\mathrm{Ag}^{+}$(Fig. 8C,D,E). Specifically, there was a dose dependent increase in protein aggregation in SUM159 cells but not in iMEC cells treated with AgNPs (Fig. 8C,E). In contrast, $\mathrm{Ag}^{+}$ exposure did not affect protein aggregation in SUM159 cells, but a modest increase was observed in iMEC cells (Fig. 8D, E).

The accumulation of misfolded proteins is cytotoxic and cells will activate stress response programs to mitigate damage. This includes activation of the integrated stress response (ISR), indicated by phosphorylation of eIF $2 \alpha$ [43], and mitogen-activated protein kinase (MAPK) signaling pathways, indicated by phosphorylation of c-Jun N-Terminal Kinase (JNK) [44]. As shown in Fig. 8F, AgNP exposure, but not $\mathrm{Ag}^{+}$, increased both p-eIF2 $\alpha$ and p-JNK in SUM159 cells. In contrast, $\mathrm{Ag}^{+}$ exposure, but not AgNPs, increased peIF2 $\alpha$ levels in iMEC cells (Fig. 8G). No change in pJNK was observed in iMEC cells after AgNP or $\mathrm{Ag}^{+}$exposure. Protein oxidation and accumulation of protein aggregates following $\mathrm{Ag}^{+}$exposure were modest in iMEC cells compared to what was observed for AgNP treated SUM159 cells, and lack of pJNK may be because damage was below the threshold needed for activation of this response. Overall, both AgNP and $\mathrm{Ag}^{+}$treatment induced protein oxidation, aggregation, and proteotoxic stress responses, but the effects were distinct from one another, dependent on cell type, and were observed to occur in proportion to the relative sensitivity of cell lines to each toxicant.

\section{AgNPs and $\mathrm{Ag}^{+}$induce distinct forms of cell death}

Because AgNPs and $\mathrm{Ag}^{+}$induced distinct forms of damage to cells, we asked if there were differences in the types of cell death caused by each. AnnexinV (AnnV) and ethidium homodimer III (EthD-III) co-staining was performed on iMEC and SUM159 cells exposed to AgNPs or $\mathrm{Ag}^{+}$for $24 \mathrm{~h}$ (Fig. 9A, B). In agreement with the relative insensitivity of iMEC cells to AgNPs, there was little change in early-stage apoptosis $\left(\mathrm{AnnV}^{+} / \mathrm{EthD}\right.$ $\mathrm{III}^{-}$staining, lower right quadrant), primary necrosis $\left(\mathrm{AnnV}^{-} / \mathrm{EthD}^{-\mathrm{III}^{+}}\right.$staining, upper left quadrant), or late-stage apoptosis/secondary necrosis $\left(\mathrm{AnnV}^{+} / \mathrm{EthD}\right.$ $\mathrm{III}^{+}$staining, upper right quadrant), even at the highest dose tested. Following $\mathrm{Ag}^{+}$exposure, iMEC cells exhibited dose dependent increase and progression from early-stage apoptosis to late-stage apoptosis/secondary necrosis without an increase in primary necrosis, indicating apoptotic cell death. A different pattern was observed for SUM159 cells after AgNP and $\mathrm{Ag}^{+}$exposure. AgNPs caused a dose dependent increase and progression of both primary necrosis and late-stage apoptosis/secondary necrosis without increasing early-stage apoptosis, indicating necrotic cell death. Although SUM159 cells were less sensitive to $\mathrm{Ag}^{+}$than iMEC cells, similar dose dependent increases and progression from early-stage apoptosis to late-stage apoptosis/secondary necrosis without an increase in primary necrosis supported apoptosis as the mechanism of cell death induced by $\mathrm{Ag}^{+}$.

AgNPs may affect the intensity of scattered light detected by flow cytometry, and quantification of changes in side scattered light has been proposed as a metric for determining AgNP uptake [45]. Consistent with previous studies, dose dependent increases in side scatter (but not forward scatter) were detected for both SUM159 and iMEC cells following AgNP exposure (Additional file 1: Fig. S5). Because AgNP treatment only affected AnnV/ EthD-III staining of SUM159 cells but not iMEC cells, changes in side scattering are unlikely to have caused this result. Studies performed by Goering and colleagues at the United States Food and Drug Administration support use of flow cytometry for assessment of AgNP induced apoptosis/necrosis, but caution that that formation of AgNP aggregates could affect data analysis [46]. Ordinarily, no gating based upon forward or side scatter is used for flow cytometry analysis 
A.

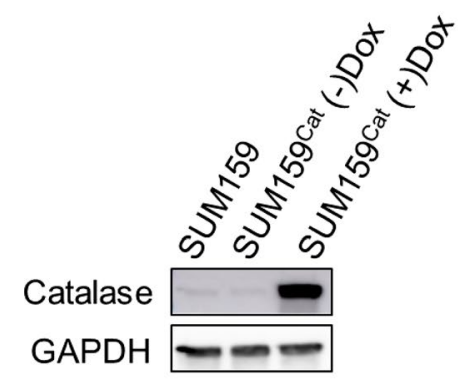

B.
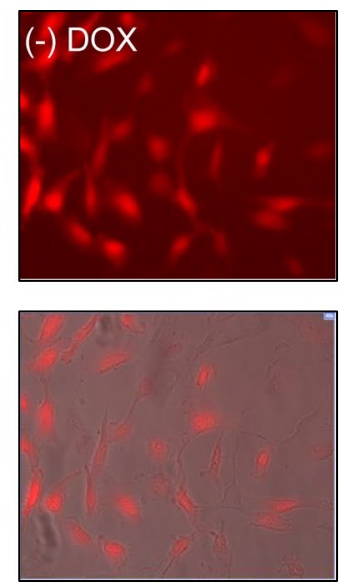

E.

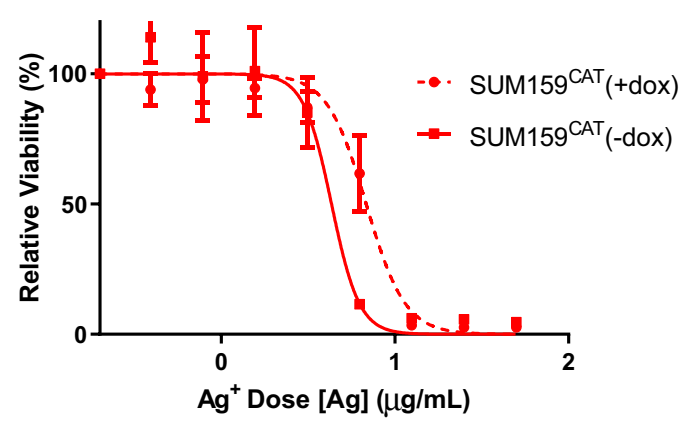

F.

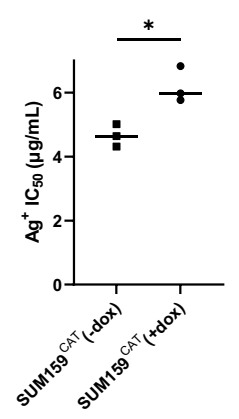

H.

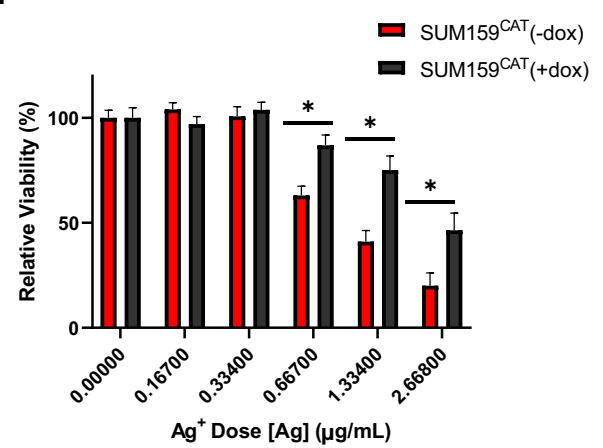

Fig. 6 (See legend on previous page.) 
(See figure on next page.)

Fig. 7 AgNPs, but not $\mathrm{Ag}^{+}$, cause lipid peroxidation. To assess lipid peroxidation, SUM159 and iMEC cells were treated with $\mathbf{A} \mathrm{AgNPs}_{\text {or }} \mathbf{B} \mathrm{Ag}^{+}$for $24 \mathrm{~h}$, stained with Liperfluo, and fluorescence was measured using flow cytometry. Statistical analysis was performed by two-way ANOVA followed by post-hoc Tukey Test. Statistical differences are indicated $\left.{ }^{*} p<0.05\right)$. C Western blotting to detect 4-HNE was performed on lysates from SUM159 and iMEC cells exposed for $24 \mathrm{~h}$ to increasing doses of AgNPs (untreated, 18.25, $37.5 \mathrm{and} 75 \mathrm{\mu g} / \mathrm{mL}$, left to right for each cell line). Western blotting to detect 4-HNE also was performed on D SUM159 or E iMEC cells exposed to AgNPs (untreated, 18.25, $37.5 \mathrm{and} 75 \mu \mathrm{g} / \mathrm{mL}^{\text {, left to right) or Ag }}$ (untreated, $0.5,1,2 \mu \mathrm{g} / \mathrm{mL}$, left to right) for $24 \mathrm{~h}$. $\beta$-actin was used as a loading control. Data are representative of a minimum of two experiments

of apoptosis/necrosis. However, gating can be used to eliminate interference due to small particulates caused by AgNP aggregation. We did not detect AgNP aggregates by DLS (Fig. 1), nor were any particulates indicative of AgNP aggregates detected in the forward and side scatter profiles of AgNP-treated SUM159 or iMEC cells (not shown). Therefore, we did not perform any gating prior to AnnV/EthD-III analysis.

To verify the flow cytometry results, we examined proapoptotic caspase signaling by western blot in AgNP and $\mathrm{Ag}^{+}$treated cells as a second metric to detect apoptosis. We observed decreased levels of full-length caspases 3 and 7, which is indicative of caspase cleavage, following $\mathrm{Ag}^{+}$exposure, but not after AgNP exposure, in iMEC (Fig. 9C) and SUM159 cells (Fig. 9D). Cleavage of caspases 3 and 7 is a key step for execution of apoptosis. The flow cytometry and western blot data indicated that $\mathrm{Ag}^{+}$, but not AgNPs, induced signs of apoptosis in SUM159 cells and iMEC cells. These data show AgNPs and $\mathrm{Ag}^{+}$ initiate distinctly different forms of cell death.

\section{Discussion}

The goals of our study were: (i) to determine precisely how AgNPs kill mammalian cells; (ii) to provide definitive proof as to whether or not this mechanism was dependent upon the presence of extracellular $\mathrm{Ag}^{+}$; (iii) and to understand how AgNP and $\mathrm{Ag}^{+}$damage propagated through cells. Two critical issues have hampered previous efforts to achieve these goals. The first is contamination of AgNP suspensions with $\mathrm{Ag}^{+}$, which prevents separating nanoparticle specific effects from those due to $\mathrm{Ag}^{+}$. The second is the fact that some cell lines exhibit greater or lesser sensitivity to AgNPs and $\mathrm{Ag}^{+}$compared to other cell lines, and thus not all cells respond similarly to exposure. To address these issues, we identified AgNPs with negligible $\mathrm{Ag}^{+}$contamination, and evaluated the responses to AgNPs and $\mathrm{Ag}^{+}$in two cell lines that differed in their relative sensitivity to AgNPs and $\mathrm{Ag}^{+}$. We found that SUM159 cells, which are a triple-negative breast cancer (TNBC) cell line, were approximately 6.5-fold more sensitive to AgNP exposure compared to iMECs, an immortalized, non-neoplastic breast epithelial cell line. We further found that SUM159 cells were 5.6fold less sensitive to $\mathrm{Ag}^{+}$compared to iMEC cells, indicating that high sensitivity to AgNPs was not predictive of similar sensitivity to $\mathrm{Ag}^{+}$. Exposure to either AgNPs or $\mathrm{Ag}^{+}$increased indications of protein thiol oxidation, accumulation of misfolded proteins, and activation of the integrated stress response in SUM159 or iMEC cells in proportion to the relative sensitivity of the cell lines to each toxicant. However, there were distinct differences between how AgNP and $\mathrm{Ag}^{+}$damage spread throughout the cells. Both $\mathrm{Ag}^{+}$and AgNP exposure increased $\mathrm{H}_{2} \mathrm{O}_{2}$ levels in these two cell lines, but catalase rescued cells from $\mathrm{Ag}^{+}$cytotoxicity and had no effect on the cytotoxicity of AgNPs. This indicates that $\mathrm{H}_{2} \mathrm{O}_{2}$ contributed to the mechanism of action of $\mathrm{Ag}^{+}$but did not play a dominant role in the cytotoxic effects of AgNPs. Instead, our data support a mechanism by which damage from AgNP exposure propagates through cells by generation of lipid peroxides, subsequent lipid peroxide mediated oxidation of proteins, and via generation of 4-HNE protein adducts. 4-HNE can diffuse out of endosomes or lysosomes and into the cytosol, enabling spread of AgNP-induced damage from endosomes to other organelles including mitochondria [42].

In the past, failure to account for $\mathrm{Ag}^{+}$contamination in AgNP dispersions before administration to cells or animals likely contributed to the contradicting data in the $\mathrm{AgNP}$ vs $\mathrm{Ag}^{+}$debate. For example, Beer et al. characterized a wide variety of commercially available and laboratory synthesized AgNPs and found that $\mathrm{Ag}^{+}$made up 2.6-5.9\% of typical laboratory-made AgNP dispersions, and various commercial preparations AgNP contained $39-69 \% \mathrm{Ag}^{+}$by mass [6]. A recent study found that $70 \%$ of the commercially available colloidal silver products tested contained exclusively $\mathrm{Ag}^{+}$with no evidence of AgNPs [47]. Because AgNPs used in our study had extremely low amounts of dissolved $\mathrm{Ag}^{+}(<0.001 \%$ by mass even after storage), we were able to independently examine $\mathrm{Ag}^{+}$and AgNP-dependent mechanistic effects.

An additional confounding factor in assessment of the toxic effects of nanomaterials, including AgNPs, is that they can interfere with assays reliant upon optical absorbance, fluorescence, or luminescence measurements [48-51]. Nanoparticles themselves could absorb or scatter light, fluoresce, or increase autofluorescence in cells. The potential for nanoparticles to affect background absorbance or fluorescence measurements in part can be accounted for by subtracting background measurements 


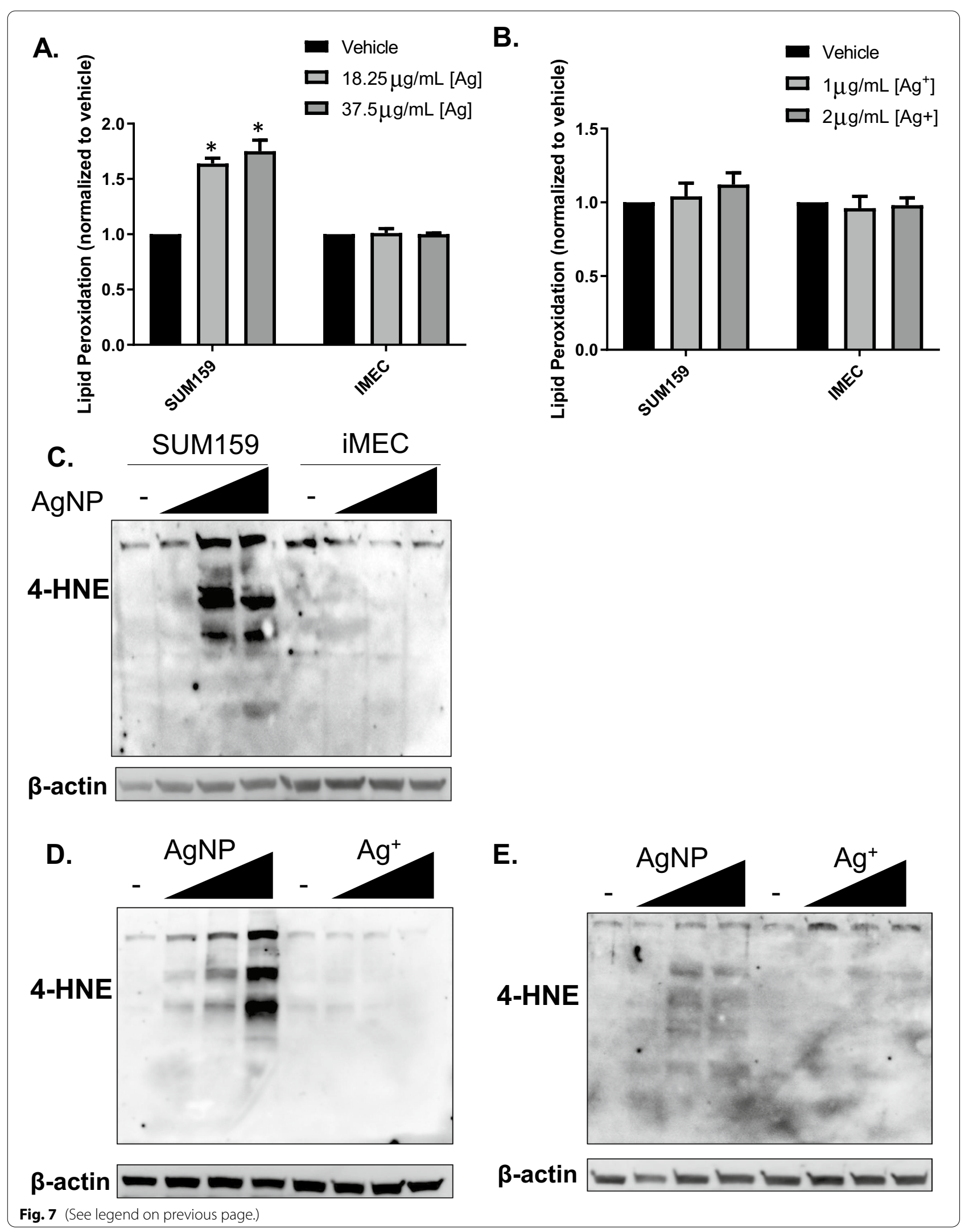




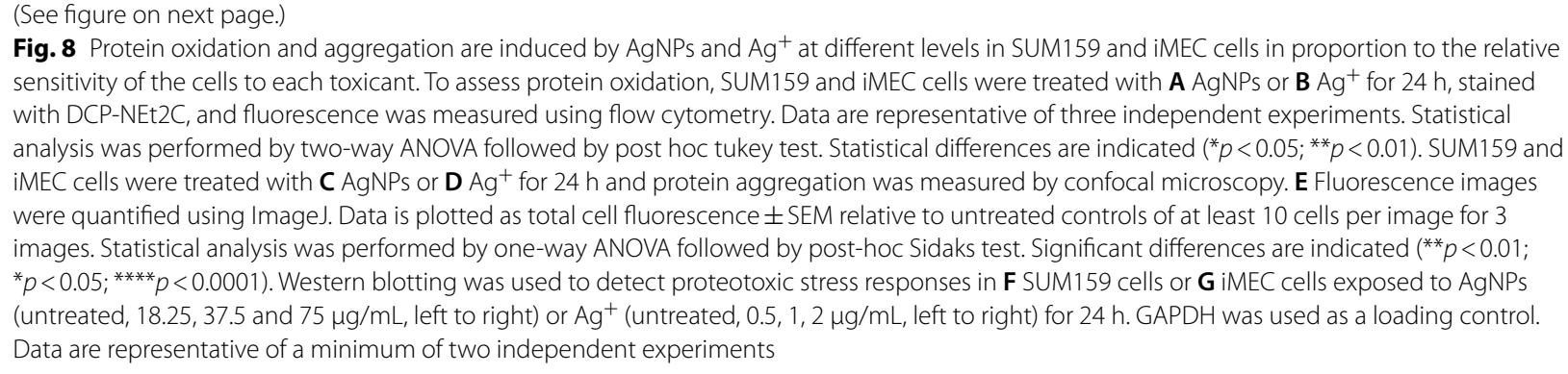

taken from label-free, nanoparticle treated cells as we have done in the studies reported here. Nanoparticles also may increase or quench fluorescence from certain fluorophores, quench luminescence, or potentially affect the reaction rates for formation of substrates used to assess cell viability [48-51]. Because these types of interference are challenging to assess under experimental conditions used for cell-based assays, cell-free systems commonly are used. For example, when dispersed in PBS, Mello et al. observed that incubation of AgNPs with MTT caused a dose dependent increase the absorbance of $540 \mathrm{~nm}$ wavelengths of light [50]. This is the wavelength most strongly absorbed by the solubilized formazan salt produced by reduction of MTT. Although the authors concluded that certain types of AgNPs could interfere assessment of cell viability based upon spectroscopic quantification MTT reduction, generation of formazan was not chemically verified, nor was any mechanism proposed by which AgNPs could increase the reduction rate of MTT. Therefore, it is unclear if AgNPs directly reduced MTT or if there were other factors which could affect optical absorbance under the experimental conditions tested. In contrast to Mello et al., investigations by Andraos et al. of the interference of AgNPs dispersed in media containing XTT (2,3-Bis-(2-methoxy-4-nitro-5-sulfophenyl)-2H-tetrazolium-5-carboxanilide), which is a tetrazolium salt used in assays similar to the MTT assay, did not identify any change in reduction of XTT due to AgNPs. However, they cautioned that under some conditions, AgNPs could mask the absorbance due to XTT or its formazan reduction product, possibly by adsorption, leading to overestimation of cytotoxicity [49].

Cell-free approaches could be misleading because they often are performed in the absence of biomolecules that are present in the extracellular environment or within cells that dictate the nanoparticle protein corona, formed by adsorption of molecules in the dispersant onto the surface of nanomaterials [52]. For AgNPs, both intra and extracellular organosulfur-containing molecules strongly adsorb or bind to the nanoparticle, altering surface properties that influence colloidal stability (e.g. $\zeta$-potential; hydrophobicity/hydrophilicity) and cell interactions, changing spectroscopic properties, and potentially affecting interactions with dyes or reagents used for performing viability assays [53]. Cell-free approaches also fail to account for confinement of nanoparticles into specific subcellular compartments and assume that all components within the assay system can freely interact. Therefore, assessment of the potential for one type of nanoparticle to interfere with various spectroscopic assays in one specific environment is not inherently generalizable to similar nanoparticles or different environments.

In the absence of an ideal system for identifying all sources of nanoparticle interference with each assay, use of multiple, complimentary metrics to evaluate specific aspects of cell responses to nanoparticles is the best available option. Here, we assessed effects of AgNPs on growth and cell death using optical absorbance (MTT assay for cell growth), fluorescence (AnnV/PI staining as indicators of phosphatidylserine exposure and loss of cell membrane integrity respectively), and combined these with complimentary, non-spectroscopic methods of growth and apoptosis including the label-free clonogenic assay, and quantification of caspase cleavage by western blot. All four assays indicated that AgNPs were significantly more cytotoxic to SUM159 cells than to iMEC cells. Based upon the differences in responses to AgNPs of the two cell lines, it is unlikely that interference of AgNPs with any assay played a dominant role. For example, a dose of $37.5 \mu \mathrm{g} / \mathrm{ml}$ decreased MTT assay absorbance measurements by 70\% for SUM159 cells, but no significant reduction in absorbance was observed for identically treated iMEC cells, indicating that effects of AgNPs were cell line dependent. No increase in absorbance, which could potentially be indicative of increased formazan formation, was observed at any of the AgNP doses tested. In a previous study, using AgNPs identical to those used here, we directly compared the results of the MTT assay with both clonogenic growth and labelfree, live cell imaging over time for assessment of the cytotoxicity of AgNPs in a panel of four TNBC and two breast epithelial cell lines [54]. All three assays were in agreement regarding the relative sensitivity of the cell 


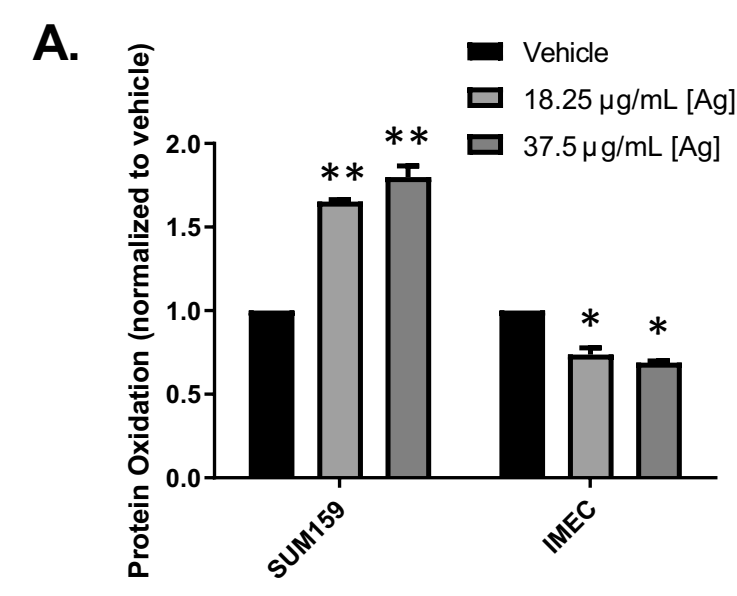

C.
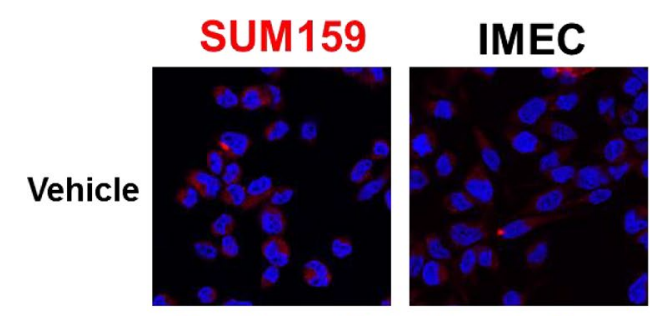

18.25

$\mu \mathrm{g} / \mathrm{mL}$

AgNP

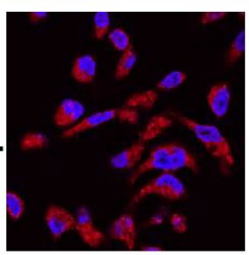

37.5

$\mu \mathrm{g} / \mathrm{mL}$

AgNP
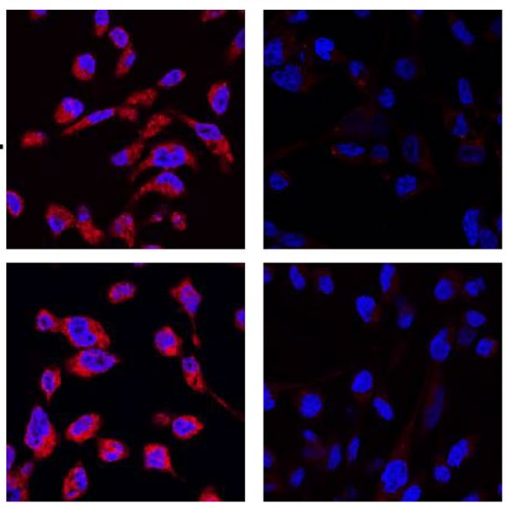

E.

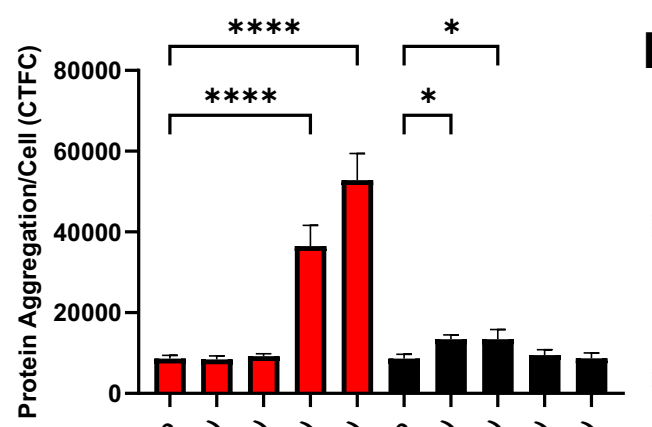

F.

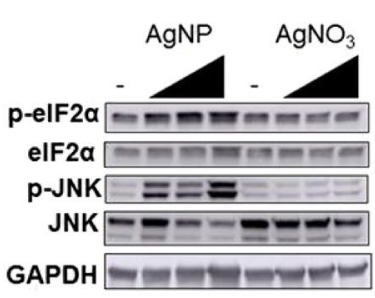

D.
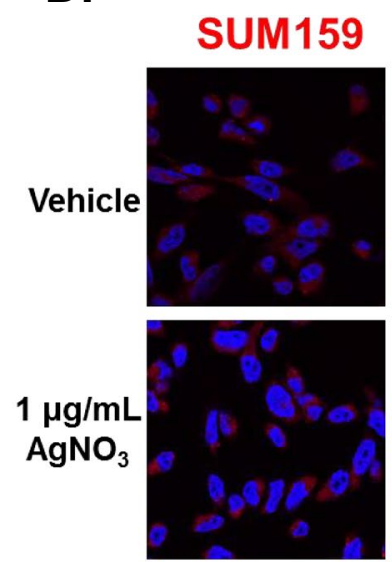

$2 \mu \mathrm{g} / \mathrm{mL}$ $\mathrm{AgNO}_{3}$

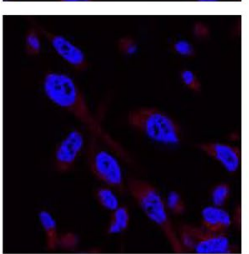

B.

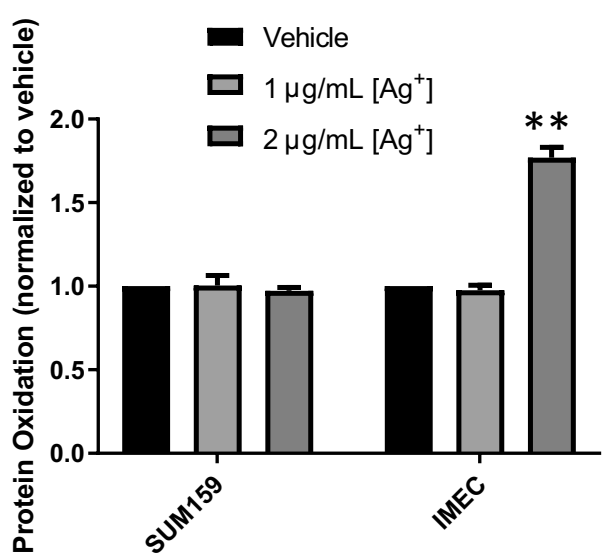

G.
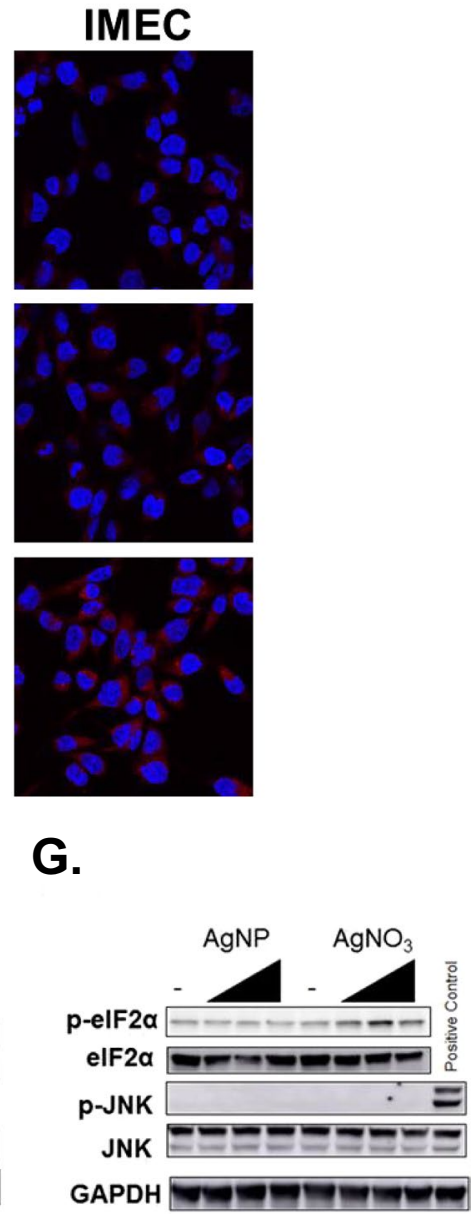

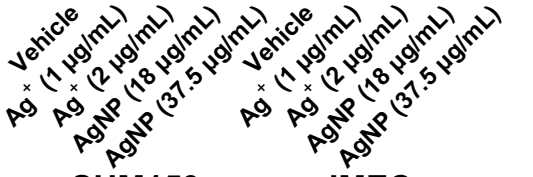

SUM159

IMEC

Fig. 8 (See legend on previous page.) 
(See figure on next page.)

Fig. 9 The mechanism of cell death induced by AgNPs differs from that of $\mathrm{Ag}^{+}$. A iMEC or B SUM159 cells were exposed to $\mathrm{AgNPs}_{\text {or }} \mathrm{Ag}^{+}$for $24 \mathrm{~h}$, co-stained with PI and AnnV, and then evaluated by flow cytometry. The percentages of cells characterized as viable (lower-left quadrant), early apoptotic (lower-right quadrant), late apoptotic (upper-right quadrant), and necrotic (upper left quadrant) are shown within each quadrant. Data are representative of a minimum of two independent experiments. C iMEC or D SUM159 cells were exposed to AgNPs or Ag for $24 \mathrm{~h}$ and full length caspase expression was detected by western blot. Protein levels relative to GAPDH loading control were quantified by densitometry. Expression of cas-7/GAPDH and cas-3/GAPDH is shown relative to levels detected in untreated control. Statistical analysis was performed using one-way ANOVA followed by post-hoc tukey test. Statistical differences are indicated $\left({ }^{*} p<0.05,{ }^{* *} p<0.01,{ }^{* * *} p<0.001\right)$

lines to AgNPs. In the same study, quantification of the uptake of AgNPs by these cell lines using inductively coupled plasma mass spectroscopy revealed that there was no correlation between the mass of AgNPs taken up and the AgNP $\mathrm{IC}_{50}$ across the six cell lines. Interference with assays due to physicochemical properties of the nanomaterial would be expected to correlate with nanoparticle uptake and be independent of cell line/cell type. Thus, our current and previous results provide strong support for a biological basis for observed differences in cytotoxicity rather than effects driven by nanoparticle interference.

In addition to assessing cytotoxic effects of AgNPs, we evaluated AgNP induced proteotoxicity using three complimentary methods. For the first, we used DCP-NEt2C, a probe we developed that is specific for labeling of sulfenic acids in mitochondrial proteins indicative of oxidation. DCP-NEt2C previously was evaluated for detecting AgNP induced protein oxidation and is suited for live cell biological imaging applications because it does not cause mitochondrial toxicity itself, nor is it affected by changes in mitochondrial membrane potential, which could be caused by AgNP exposure [35]. Although DCP-NEt2C is specific for detection of oxidized thiols in mitochondria, we observed DCP-Net2C labeling to be correlated with other metrics of total thiol oxidation in lung cells treated with AgNPs [13]. Furthermore, we previously found that an increase in sulfenylated proteins following AgNP treatment was characteristic of AgNP sensitive breast and lung cancer cells using biotinylated, dimedonebased probes to detect protein sulfenic acids by western blot [9], and by quantification of total reversible protein thiol oxidation using mass spectrometry [14]. The second method we used here to assess proteotoxicity involved staining with proteostat after paraformaldehyde fixation for the formation of protein aggregates in AgNP-treated cells. Proteostat is a type of "turn-on" fluorophore called a molecular rotor. When free to move, fluorescence is low, but when proteostat is entrapped in a hydrophobic pocket of a protein aggregate, motion is restricted, and the molecule becomes highly fluorescent. Increased proteostat fluorescence was detected only in AgNP treated SUM159 cells, and not in AgNP treated iMEC cells or in untreated cells, indicating dependency on both AgNP exposure and cell type. Lastly, we used western blotting to determine if the protein oxidation and protein aggregation observed by flow cytometry or confocal fluorescence microscopy activated cell stress pathways in response to proteotoxicity. All three metrics indicated that AgNPs increased proteotoxicity in SUM159 cells at doses that did not affect iMEC cells. The agreement between the three assays, which were performed in live cells, fixed cells, or in cell lysates, greatly strengthens the accuracy of conclusions drawn regarding AgNP induced proteotoxicity compared to use of any single assay.

To understand the potential cause of protein oxidation, we assessed the effects of AgNPs on total ROS, $\mathrm{H}_{2} \mathrm{O}_{2}$, and lipid peroxides. Detection of ROS presents specific challenges due to need for quantification in live cells. In our studies, we used two different dyes for evaluation of ROS: CM- $\mathrm{H}_{2}$ DCF-DA and PO1. Oxidation of $\mathrm{H}_{2} \mathrm{DCF}$ yields a highly fluorescent derivative, DCF, which is commonly used to quantify overall ROS, though there are several caveats including: lack of specificity for detection of $\mathrm{H}_{2} \mathrm{O}_{2}$; potential for oxidation by other several one-electron oxidizing species; potential for transition metals or peroxidases to catalyze its oxidation; and DCF radicals can react with oxygen to generate ROS [55]. In contrast, boronate-based fluorescent probes like PO1 directly react with $\mathrm{H}_{2} \mathrm{O}_{2}$, which causes boronate deprotection resulting in a highly fluorescent derivative [56]. Significant increases in DCF and PO1 fluorescence were detected by confocal laser scanning microscopy in both SUM159 and iMEC cells after AgNP or $\mathrm{Ag}^{+}$exposure. We validated the specificity of the dyes for detecting $\mathrm{H}_{2} \mathrm{O}_{2}$ through use PEG-catalase treatment and genetically over-expressed catalase, both of which eliminated treatment-induced increases in fluorescence for each dye. Because there was no evidence that the AgNPs used in our studies directly increased oxidation of either dye in the presence of catalase, the increased fluorescence was likely due to increased ROS rather than an artifact due to nanoparticle interference. Under some, cell-free conditions, AgNPs may quench DCF fluorescence [49], and therefore our results may underestimate $\mathrm{ROS}$ or $\mathrm{H}_{2} \mathrm{O}_{2}$ production, though this would not affect our overall conclusions. 
A.
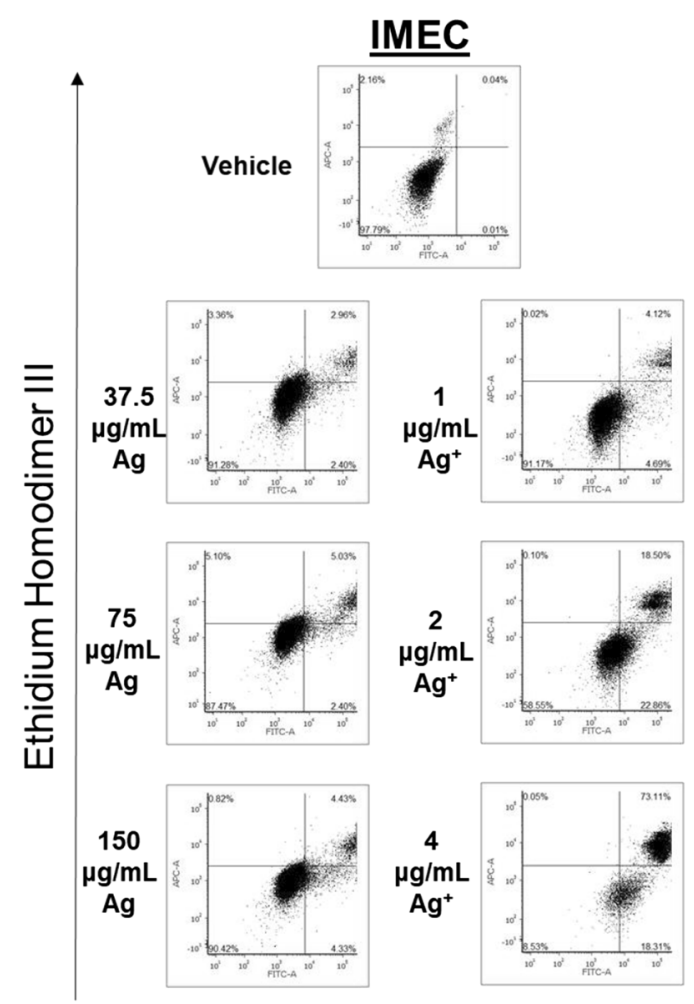

B.

SUM159

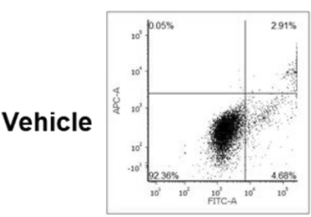

37.5 $\mu \mathrm{g} / \mathrm{mL}$

$\mathrm{Ag}$

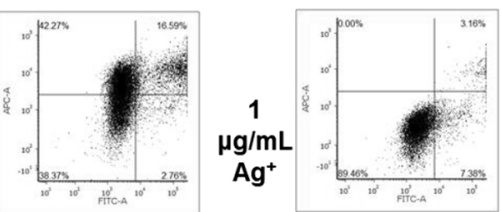

75 $\mu \mathrm{g} / \mathrm{mL}$

$\mathrm{Ag}$
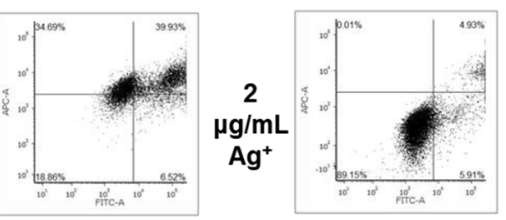

$\mu \mathrm{g} / \mathrm{mL}$

Ag
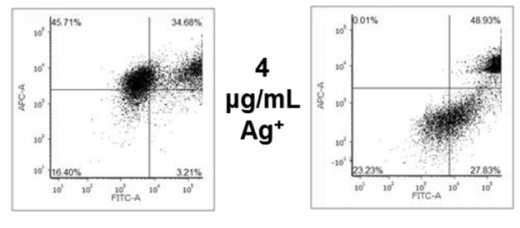

C.

IMEC
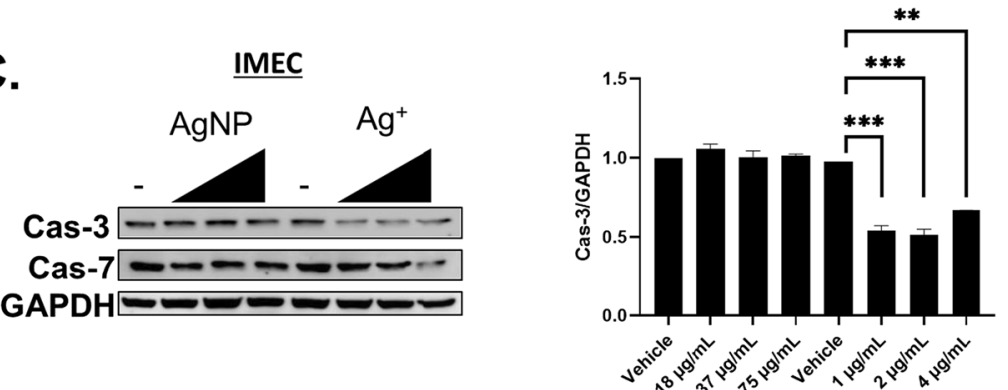

D.

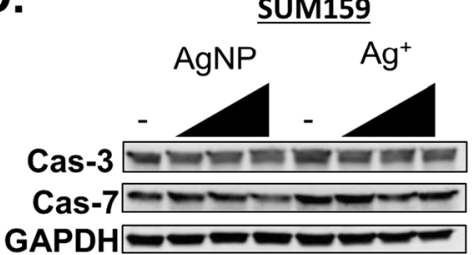

Annexin V

$\mathrm{Ag}^{+}$

AgNP

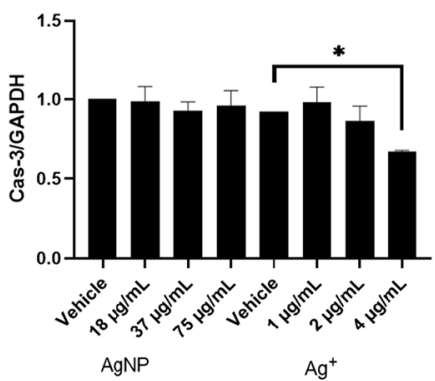

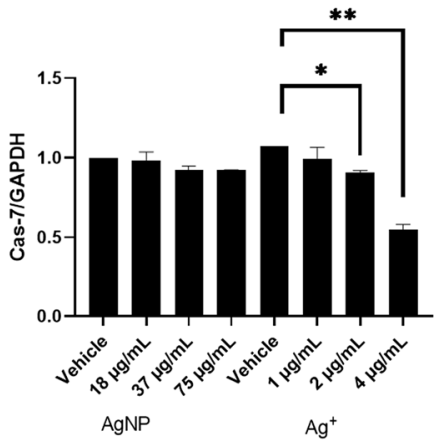

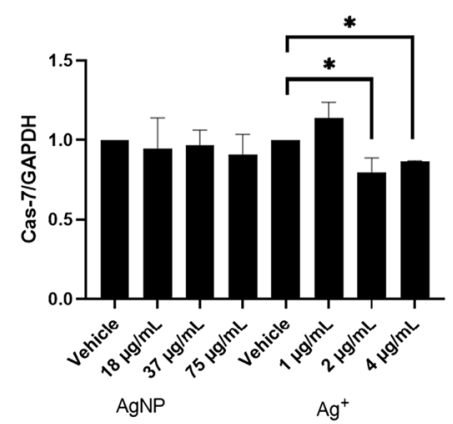

Fig. 9 (See legend on previous page.) 
We used flow cytometry to detect oxidation of phospholipids in cell membranes using a lipid peroxidespecific fluorescent probe called Liperfluo. Following quantification of changes in Liperfluo fluorescence by flow cytometry, we detected a significant increase in fluorescence indicative of lipid peroxidation in AgNP treated SUM159 cells but not in iMEC cells. As a nonfluorescent means of validating our data, we quantified 4-HNE adducts by western blot, and again observed an increase in 4-HNE adducts in SUM159 cells, but not in iMEC cells. $\mathrm{Ag}^{+}$exposure did not increase Liperfluo fluorescence or 4-HNE adducts in either cell line, despite increasing both $\mathrm{H}_{2} \mathrm{O}_{2}$ and total ROS levels, providing additional evidence that these observations were indicative of lipid peroxidation and not merely a reflection of changes in the overall redox state of the cells following AgNP exposure.

Some studies suggest that ROS generated after AgNP exposure is a critical component of their cytotoxic mechanism $[15,22,25]$. In contrast, we show that both $\mathrm{Ag}^{+}$ and AgNPs increase $\mathrm{H}_{2} \mathrm{O}_{2}$, but only $\mathrm{Ag}^{+}$-induced cell death was rescued by catalase. Previous studies using glutathione (GSH) or N-acetyl cysteine (NAC) as antioxidants to mitigate damage due to AgNP-induced ROS may be misleading because both can directly chelate free $\mathrm{Ag}^{+}$ or bind to AgNPs [28]. These effects, rather than ROS mitigation, may explain previous observations that GSH or NAC reduce AgNP cytotoxicity. NAC also increases GSH levels, and GSH plays a critical role in detoxifying lipid peroxides [32] as well as 4-HNE adducts [57], and thus mitigating effects on AgNP-induced lipid peroxides also may contribute to their capacity to rescue AgNPinduced cell death. In well-controlled studies comparing the potential genotoxicity of PVP-coated AgNPs to $\mathrm{Ag}^{+}$, $\mathrm{Li}$ et al. also concluded that the mechanisms by which AgNPs and $\mathrm{Ag}^{+}$induced genotoxicity differ from each other [27]. They showed that there was minimal release of $\mathrm{Ag}^{+}$from their AgNPs, and that AgNPs themselves, but not $\mathrm{Ag}^{+}$, were capable of increasing hydroxyl radicals in cells, further supporting a nanoparticle specific mechanism of action. Importantly, they observed that Trolox, a vitamin E analogue, protected against both AgNP and $\mathrm{Ag}^{+}$toxicity, but NAC protected only against $\mathrm{Ag}^{+}$. Vitamin $\mathrm{E}$ and its analogues act as peroxyl radical scavengers capable of terminating chain reactions caused by lipid peroxyl radicals abstracting a hydrogen atom from a neighboring polyunsaturated fatty acid in a lipid membrane. Thus, the protective effects of Trolox against AgNPs observed by Li et al. [27] are consistent with a lipid peroxide driven mechanism of AgNP toxicity. However, vitamin $\mathrm{E}$ is unable to block the initial generation of lipid peroxyl radicals, nor does it prevent degradation of lipid peroxides into toxic end products such as 4-HNE.
Furthermore, vitamin $\mathrm{E}$ is not specifically an antioxidant for lipid peroxides but also is involved in multiple biological processes, and in some cases acts as a pro-oxidant as previously reviewed [58]. Because AgNPs, but not $\mathrm{Ag}^{+}$, cause increases in lipid peroxidation and 4-HNE-adduct formation, it is clear that different forms of damage are induced. To fully establish causality, it will be necessary to perform additional studies to modulate the lipid profile of AgNP sensitive or insensitive cells in order to enrich or deplete lipid membranes for highly oxidizable lipid species.

The AgNPs used for the majority of our studies consist of only two components: a nominal $25 \mathrm{~nm}$ silver core and a dense stabilizing layer of PVP, a polymer considered generally safe by the United States Food and Drug Administration, making these nanoparticles suitable for further biomedical development. For these studies, PVP serves the purpose of stabilizing the AgNPs such that when the dry powder is dispersed in aqueous solution, the nanoparticles remain well dispersed (unaggregated) under physiologically relevant ionic strength and $\mathrm{pH}$, and do not behave as a larger sized aggregate rather than as nanoscale particles. One challenge in generalizing findings regarding the toxicity profile of nanomaterials is that the specific physicochemical and toxicological properties of a nanoparticle depend not only on the material making up the core, but also on the size, shape, coating, presence of contaminants, and the environment in which testing is performed. However, in an earlier study [11], we found that the TNBC-selective cytotoxic property of AgNPs was retained by particles with various sizes $(5-150 \mathrm{~nm}$ diameters), shapes (spheres and triangular prisms), or capping agents (PVP, chitosan, and silica). The environment in which AgNPs are dispersed also may affect their dissolution, and alter their toxicity profile. For example, inhaled AgNPs may dissolve, release $\mathrm{Ag}^{+}$, and potentially reform into smaller nanoparticles due to interaction with biomolecules in the lung extracellular fluid $[59,60]$. Precisely how AgNP toxicity differs when assessed in varying physiological environments remains to be determined.

We and others previously showed that AgNPs were highly cytotoxic to multiple TNBC cell lines at doses that were not toxic to non-neoplastic breast cells [911, 54]. Thus, an extension of our current work on the mechanism of AgNP-induced cell death is the potential to exploit this knowledge for breast cancer therapy. In earlier studies demonstrating the sensitivity to TNBC cells to AgNPs [10,11], it also was observed that AgNPs induced endoplasmic reticulum (ER) stress, which occurs when misfolded proteins accumulate in the ER. Because AgNPs do not localize to the ER, it was unclear how ER stress was induced. Misfolded proteins can accumulate in the ER if protein degradation machinery, including 
the ubiquitin proteasome system and autophagy, is overwhelmed by damaged proteins generated elsewhere in the cell [61]. We observed that AgNPs increased lipid peroxides in TNBC SUM159 cells, but not in iMEC cells. These lipid peroxides can oxidize proteins, or degrade to 4-HNE, which reacts with proteins to form adducts. Both types of damage cause protein misfolding and aggregation and can trigger ER stress and ISR through eIF2 $\alpha$ signaling. The results of our cell death studies show that AgNPs induce necrosis in SUM159 cells at doses that were not toxic to iMEC cells. This is consistent with several studies that show that AgNPs induce necrosis [62, 63]. In contrast, $\mathrm{Ag}^{+}$treatment caused apoptosis at lower doses in iMEC cells compared to SUM159 cells. Accumulation of 4-HNE and the resulting buildup of protein aggregates in the cell are highly toxic and have been shown to initiate necrotic cell death [64, 65], whereas cell death caused by excess ROS is more often mediated by apoptosis [66]. Therefore, the difference in cell death pathways could be due to the induction of lipid peroxidation by $\mathrm{AgNPs}$ but not $\mathrm{Ag}^{+}$. TNBCs are enriched in longchain, polyunsaturated fatty acids (PUFAs) [67], which are prone to peroxidation, and this may be an underlying factor that drives their sensitivity to AgNPs. Accumulation of lipid peroxides is also involved in a form of nonapoptotic, iron-dependent, programmed cell death called ferroptosis $[68,69]$. It is not known whether AgNPs initiate ferroptosis and additional studies also will be necessary in order to confirm this.

Although we show mechanistic differences between responses of cells exposed to AgNPs or extracellular $\mathrm{Ag}^{+}$, we are unable to rule out effects caused by $\mathrm{Ag}^{+}$released from AgNPs after they are taken up. Additionally, the precise reason why exposure to AgNPs but not $\mathrm{Ag}^{+}$ causes lipid peroxidation remains to be identified. This may be driven by the different uptake pathways of AgNPs and $\mathrm{Ag}^{+}$, which would result in localization to distinct sites in the cells. AgNPs are taken up by phagocytic and endocytic pathways [18] and reside in membrane bound vesicles. AgNPs may directly oxidize unsaturated fatty acids in endosomal membranes or degrade in endosomes to release $\mathrm{Ag}^{+}$in high concentration, which then reacts with unsaturated fatty acids. In contrast, $\mathrm{Ag}^{+}$can enter cells through copper ion transporters $[16,17]$ and accumulate in the cytosol. When $\mathrm{Ag}^{+}$is taken up as an ion, lack of proximity or low concentration of $\mathrm{Ag}^{+}$near endosomal lipid membranes may limit effects of $\mathrm{Ag}^{+}$on lipid peroxidation, or $\mathrm{Ag}^{+}$may rapidly react with thiols in the cytosol rather than with lipids. The tools necessary to measure intracellular silver ions and silver ion-ligand species are now emerging [20,70,71], but direct measurement of intracellular dissolution of AgNPs remains a major challenge [8].

\section{Conclusion}

In conclusion, our integrated approach to assessing $\mathrm{AgNP}$ and $\mathrm{Ag}^{+}$cytotoxicity indicates distinct differences exist in the responses of mammalian cells to AgNPs and $\mathrm{Ag}^{+}$. Specifically, AgNPs drive cell death through a mechanism that involves lipid peroxidation, proteotoxic stress, and necrotic cell death, whereas $\mathrm{Ag}^{+}$exposure increases $\mathrm{H}_{2} \mathrm{O}_{2}$, which drives oxidative stress and apoptotic cell death. This work identifies a specific mechanism by which AgNPs kill mammalian cells that is not dependent upon the contribution of $\mathrm{Ag}^{+}$released in extracellular media. Understanding precisely which factors drive the toxicity of AgNPs is essential for biomedical applications such as cancer therapy, and of importance to identifying consequences of unintended exposures.

\section{Supplementary Information}

The online version contains supplementary material available at https://doi. org/10.1186/s12989-021-00430-1.

Additional file 1. Supplementary Figures S1-S5.

\section{Acknowledgements}

We thank K Grant and P Graham for assistance in sample preparation for TEM, Y Karpova for establishing cell lines and performing mycoplasma tests, B Bickford for assistance with fluorescence microscopy, and J Strupe for performing mycoplasma tests. We thank J Whitesides for assistance with flow cytometry.

\section{Authors' contributions}

MMR and RS conceptualized, designed and performed the research, and wrote the manuscript. CMS, JS, and SRS performed the research and edited the manuscript. GLD, DS, and CMF supervised the research, provided essential reagents and expertise, critically reviewed and edited the manuscript. All authors read and approved the final manuscript.

\section{Funding}

The research in this work was supported by NIH/NCI R01CA207222, R33CA177461, P01CA217797, R01CA18280, and NIH/NIEHS R33ES025645. Support for pre/post-doctoral training was provided in part by NIH/NIGMS T32GM127261. Assistance provided by the Wake Forest Comprehensive Cancer Center (WFUCCC) Cell Engineering Shared Resource, the Cellular Imaging Shared Resource, and the Flow Cytometry Shared Resource was supported in part by NIH/NCI CCSG P30CA012197. Assistance provided by the University of lowa Holden Comprehensive Cancer Center Radiation and Free Radical Research Core was supported in part by P30CA086862. The National Science Foundation's Major Research Instrumentation Program supported the microwave-assisted digestion and the ICP-MS systems (grant CHE-1531698). The content is solely the responsibility of the authors and does not necessarily represent the official views of the NIH or NSF.

Availability of data and materials

Data sharing is not applicable to this article as no datasets were generated or analysed during the current study.

\section{Declarations}

Ethical approval and consent to participate Not applicable.

Consent for publication Not applicable. 


\section{Competing interests}

RS has filed for protection of intellectual property relating to molecular signatures predictive of cancer sensitivity to silver nanoparticles (WO 2018/231790 Al). CMF is co-founder of Xoder Technologies, LLC, which provides consulting services and commercializes reagents for redox investigations.

\section{Author details}

${ }^{1}$ Department of Cancer Biology, Wake Forest School of Medicine, Medical Center Blvd., Winston-Salem, NC 27157, USA. ${ }^{2}$ Department of Chemistry, Wake Forest University, Winston-Salem, NC 27109, USA. ${ }^{3}$ Free Radical and Radiation Biology Program, Department of Radiation Oncology, Holden Comprehensive Cancer Center, University of lowa, lowa City, IA 52242, USA. ${ }^{4}$ Department of Internal Medicine, Section of Molecular Medicine, Wake Forest School of Medicine, Winston-Salem, NC 27157, USA. ${ }^{5}$ Comprehensive Cancer Center of Wake Forest Baptist Medical Center, Winston Salem, NC 27157, USA.

Received: 17 April 2021 Accepted: 21 September 2021

Published online: 14 October 2021

\section{References}

1. Reidy B, Haase A, Luch A, Dawson KA, Lynch I. Mechanisms of silver nanoparticle release, transformation and toxicity: a critical review of current knowledge and recommendations for future studies and applications. Materials. 2013;6(6):2295-350.

2. Tortella GR, Rubilar O, Duran N, Diez MC, Martinez M, Parada J, Seabra $A B$. Silver nanoparticles: Toxicity in model organisms as an overview of its hazard for human health and the environment. J Hazard Mater. 2020;390:121974.

3. Falconer JL, Grainger DW. In vivo comparisons of silver nanoparticle and silver ion transport after intranasal delivery in mice. J Control Release. 2018;269:1-9.

4. Falconer JL, Alt JA, Grainger DW. Comparing ex vivo and in vitro translocation of silver nanoparticles and ions through human nasal epithelium. Biomaterials. 2018;171:97-106.

5. Navarro E, Piccapietra F, Wagner B, Marconi F, Kaegi R, Odzak N, Sigg L, Behra R. Toxicity of silver nanoparticles to Chlamydomonas reinhardtii. Environ Sci Technol. 2008;42(23):8959-64.

6. Beer C, Foldbjerg R, Hayashi Y, Sutherland DS, Autrup H. Toxicity of silver nanoparticles - nanoparticle or silver ion? Toxicol Lett. 2012;208(3):286-92.

7. Kawata K, Osawa M, Okabe S. In vitro toxicity of silver nanoparticles at noncytotoxic doses to HepG2 human hepatoma cells. Environ Sci Technol. 2009;43(15):6046-51.

8. Smith JN, Thomas DG, Jolley H, Kodali VK, Littke MH, Munusamy P, Baer DR, Gaffrey MJ, Thrall BD, Teeguarden JG. All that is silver is not toxic: silver ion and particle kinetics reveals the role of silver ion aging and dosimetry on the toxicity of silver nanoparticles. Part Fibre Toxicol. 2018;15:17.

9. Swanner J, Mims J, Carroll DL, Akman SA, Furdui CM, Torti SV, Singh RN. Differential cytotoxic and radiosensitizing effects of silver nanoparticles on triple-negative breast cancer and non-triple-negative breast cells. Int J Nanomedicine. 2015:10:3937-53.

10. Simard J, Durocher I, Girard D. Silver nanoparticles induce irremediable endoplasmic reticulum stress leading to unfolded protein response dependent apoptosis in breast cancer cells. Apoptosis Int J Program Cell Death 2016:21(11):1279-90.

11. Swanner J, Fahrenholtz C, Tenvooren I, Bernish B, Sears J, Hooker A, Furdui C, Alli E, Li W, Donati G, et al. Silver nanoparticles selectively treat triplenegative breast cancer cells without affecting non-malignant breast epithelial cells in vitro and in vivo. FASEB bioAdvances. 2019;1(10):639-60

12. Fahrenholtz CD, Swanner J, Ramirez-Perez M, Singh RN. Heterogeneous responses of ovarian cancer cells to silver nanoparticles as a single agent and in combination with Cisplatin. J Nanomater. 2017;2017:10.

13. Holmila RJ, Vance SA, King SB, Tsang AW, Singh R, Furdui CM. Silver nanoparticles induce mitochondrial protein oxidation in lung cells impacting cell cycle and proliferation. Antioxidants (Basel). 2019;8(11):639-60.

14. Holmila R, Wu H, Lee J, Tsang AW, Singh R, Furdui CM. Integrated Redox Proteomic Analysis Highlights New Mechanisms of Sensitivity to Silver Nanoparticles. Mol Cell Proteomics. 2021;10:100073.
15. Guo DW, Zhu LY, Huang ZH, Zhou HX, Ge Y, Ma WJ, Wu J, Zhang XY, Zhou $X F$, Zhang $Y$, et al. Anti-leukemia activity of PVP-coated silver nanoparticles via generation of reactive oxygen species and release of silver ions. Biomaterials. 2013;34(32):7884-94.

16. Lee J, Pena MMO, Nose Y, Thiele DJ. Biochemical characterization of the human copper transporter Ctr1. J Biol Chem. 2002;277(6):4380-7.

17. Bertinato J, Cheung L, Hoque R, Plouffe LJ. Ctr1 transports silver into mammalian cells. J Trace Elem Med Bio. 2010;24(3):178-84.

18. Wu MY, Guo HB, Liu L, Liu Y, Xie LM. Size-dependent cellular uptake and localization profiles of silver nanoparticles. Int J Nanomed. 2019;14:4247-59.

19. Park EJ, Yi J, Kim Y, Choi K, Park K. Silver nanoparticles induce cytotoxicity by a Trojan-horse type mechanism. Toxicol In Vitro. 2010;24(3):872-8.

20. Hsiao IL, Hsieh YK, Wang CF, Chen IC, Huang YJ. Trojan-horse mechanism in the cellular uptake of silver nanoparticles verified by direct intra- and extracellular silver speciation analysis. Environ Sci Technol. 2015;49(6):3813-21.

21. Lim HK, Asharani PV, Hande MP. Enhanced genotoxicity of silver nanoparticles in DNA repair deficient Mammalian cells. Front Genet. 2012;3:104.

22. Hsin YH, Chen CF, Huang S, Shih TS, Lai PS, Chueh PJ. The apoptotic effect of nanosilver is mediated by a ROS- and JNK-dependent mechanism involving the mitochondrial pathway in NIH3T3 cells. Toxicol Lett. 2008;179(3):130-9.

23. McShan D, Ray PC, Yu H. Molecular toxicity mechanism of nanosilver. J Food Drug Anal. 2014;22(1):116-27.

24. Foldbjerg R, Dang DA, Autrup H. Cytotoxicity and genotoxicity of silver nanoparticles in the human lung cancer cell line, A549. Arch Toxicol. 2011;85(7):743-50.

25. Mei N, Zhang Y, Chen Y, Guo X, Ding W, Ali SF, Biris AS, Rice P, Moore MM, Chen T. Silver nanoparticle-induced mutations and oxidative stress in mouse lymphoma cells. Environ Mol Mutagen. 2012;53(6):409-19.

26. De Matteis V, Malvindi MA, Galeone A, Brunetti V, De Luca E, Kote S, Kshirsagar P, Sabella S, Bardi G, Pompa PP. Negligible particle-specific toxicity mechanism of silver nanoparticles: the role of $\mathrm{Ag}+$ ion release in the cytosol. Nanomedicine. 2015;11(3):731-9.

27. Li Y, Qin T, Ingle T, Yan J, He W, Yin JJ, Chen T. Differential genotoxicity mechanisms of silver nanoparticles and silver ions. Arch Toxicol. 2017:91(1):509-19.

28. Ferreira LAB, dos Reis SB, da Silva ED, Cadore S, Bernardes JD, Duran N, de Jesus MB. Thiol-antioxidants interfere with assessing silver nanoparticle cytotoxicity. Nanomed-Nanotechnol. 2020;24:139.

29. Saleeb N, Robinson B, Cavanagh J, Ross J, Munir K, Gooneratne R. Antioxidant enzyme activity and lipid peroxidation in aporrectodea caliginosa earthworms exposed to silver nanoparticles and silver nitrate in spiked soil. Environ Toxicol Chem. 2020;39(6):1257-66.

30. Xiang QQ, Wang D, Zhang JL, Ding CZ, Luo X, Tao J, Ling J, Shea D, Chen LQ. Effect of silver nanoparticles on gill membranes of common carp: Modification of fatty acid profile, lipid peroxidation and membrane fluidity. Environ Pollut. 2020;256:113504.

31. Paciorek P, Zuberek M, Grzelak A. Products of lipid peroxidation as a factor in the toxic effect of silver nanoparticles. Materials. 2020;13(11):2460.

32. Gaschler MM, Stockwell BR. Lipid peroxidation in cell death. Biochem Biophys Res Commun. 2017:482(3):419-25.

33. Brandt KE, Falls KC, Schoenfeld JD, Rodman SN, Gu Z, Zhan F, Cullen JJ, Wagner BA, Buettner GR, Allen BG, et al. Augmentation of intracellular iron using iron sucrose enhances the toxicity of pharmacological ascorbate in colon cancer cells. Redox Biol. 2018;14:82-7.

34. Spitz DR, Elwell JH, Sun Y, Oberley LW, Oberley TD, Sullivan SJ, Roberts RJ. Oxygen toxicity in control and H2O2-resistant Chinese hamster fibroblast cell lines. Arch Biochem Biophys. 1990;279(2):249-60.

35. Holmila RJ, Vance SA, Chen X, Wu H, Shukla K, Bharadwaj MS, Mims J, Wary Z, Marrs G, Singh R, et al. Mitochondria-targeted Probes for Imaging Protein Sulfenylation. Sci Rep-Uk. 2018;8:6635.

36. Bienert GP, Chaumont F. Aquaporin-facilitated transmembrane diffusion of hydrogen peroxide. Bba-Gen Subjects. 2014;1840(5):1596-604.

37. Schoenfeld JD, Sibenaller ZA, Mapuskar KA, Bradley MD, Wagner BA, Buettner GR, Monga V, Milhem M, Spitz DR, Allen BG. Redox active metals and $\mathrm{H}_{2} \mathrm{O} 2$ mediate the increased efficacy of pharmacological ascorbate in combination with gemcitabine or radiation in pre-clinical sarcoma models. Redox Biol. 2018;14:417-22. 
38. Dickinson BC, Huynh C, Chang CJ. A palette of fluorescent probes with varying emission colors for imaging hydrogen peroxide signaling in living cells. J Am Chem Soc. 2010;132(16):5906-15.

39. Yamanaka K, Saito Y, Sakiyama J, Ohuchi Y, Oseto F, Noguchi N. A novel fluorescent probe with high sensitivity and selective detection of lipid hydroperoxides in cells. Rsc Adv. 2012;2(20):7894-900.

40. Gupta V, Carroll KS. Sulfenic acid chemistry, detection and cellular lifetime. Bba-Gen Subjects. 2014;1840(2):847-75.

41. Hackett MJ, Smith SE, Caine S, Nichol H, George GN, Pickering IJ, Paterson PG. Novel bio-spectroscopic imaging reveals disturbed protein homeostasis and thiol redox with protein aggregation prior to hippocampal CA1 pyramidal neuron death induced by global brain ischemia in the rat. Free Radic Biol Med. 2015;89:806-18.

42. Castro JP, Jung T, Grune T, Siems W. 4-Hydroxynonenal (HNE) modified proteins in metabolic diseases. Free Radical Bio Med. 2017;111:309-15.

43. McConkey DJ. The integrated stress response and proteotoxicity in cancer therapy. Biochem Biophys Res Commun. 2017;482(3):450-3.

44. Darling NJ, Cook SJ. The role of MAPK signalling pathways in the response to endoplasmic reticulum stress. Bba-Mol Cell Res. 2014;1843(10):2150-63.

45. Zucker RM, Ortenzio J, Degn LL, Lerner JM, Boyes WK. Biophysical comparison of four silver nanoparticles coatings using microscopy, hyperspectral imaging and flow cytometry. PLoS ONE. 2019;14(7):e0219078.

46. Kumar G, Degheidy H, Casey BJ, Goering PL. Flow cytometry evaluation of in vitro cellular necrosis and apoptosis induced by silver nanoparticles. Food Chem Toxicol. 2015;85:45-51.

47. Kumar A, Goia DV. Comparative analysis of commercial colloidal silver products. Int J Nanomed. 2020;15:10425-34.

48. Oostingh GJ, Casals E, Italiani P, Colognato R, Stritzinger R, Ponti J, Pfaller T, Kohl Y, Ooms D, Favilli F, et al. Problems and challenges in the development and validation of human cell-based assays to determine nanoparticle-induced immunomodulatory effects. Part Fibre Toxicol. 2011;8(1):8.

49. Andraos C, Yu IJ, Gulumian M. Interference: A Much-Neglected Aspect in High-Throughput Screening of Nanoparticles. Int J Toxicol. 2020;39(5):397-421.

50. Mello DF, Trevisan R, Rivera N, Geitner NK, Di Giulio RT, Wiesner MR, HsuKim H, Meyer JN. Caveats to the use of MTT, neutral red, Hoechst and Resazurin to measure silver nanoparticle cytotoxicity. Chem-Biol Interact. 2020:315:108868

51. Eldridge BN, Xing F, Fahrenholtz CD, Singh RN. Evaluation of multiwalled carbon nanotube cytotoxicity in cultures of human brain microvascular endothelial cells grown on plastic or basement membrane. Toxicol In Vitro. 2017:41:223-31.

52. Walczyk D, Bombelli FB, Monopoli MP, Lynch I, Dawson KA. What the Cell "Sees" in Bionanoscience. J Am Chem Soc. 2010;132(16):5761-8.

53. Miclaus T, Beer C, Chevallier J, Scavenius C, Bochenkov VE, Enghild JJ, Sutherland DS. Dynamic protein coronas revealed as a modulator of silver nanoparticle sulphidation in vitro. Nat Commun. 2016:7:11.

54. Snyder CM, Rohde MM, Fahrenholtz CD, Swanner J, Sloop J, Donati GL, Furdui CM, Singh R. Low doses of silver nanoparticles selectively induce lipid peroxidation and proteotoxic stress in mesenchymal subtypes of triple-negative breast cancer. Cancers (Basel). 2021;13(16):4217.

55. Dikalov SI, Harrison DG. Methods for detection of mitochondrial and cellular reactive oxygen species. Antioxid Redox Signal. 2014;20(2):372-82.

56. Lin VS, Dickinson BC, Chang CJ. Boronate-based fluorescent probes: imaging hydrogen peroxide in living systems. Methods Enzymol. 2013;526:19-43.
57. Spitz DR, Sullivan SJ, Malcolm RR, Roberts RJ. Glutathione dependent metabolism and detoxification of 4-hydroxy-2-nonenal. Free Radical Bio Med. 1991:11(4):415-23.

58. Miyazawa T, Burdeos GC, Itaya M, Nakagawa K, Miyazawa T. Vitamin E: regulatory redox interactions. IUBMB Life. 2019;71(4):430-41.

59. Kreyling WG, Holzwarth U, Hirn S, Schleh C, Wenk A, Schaffler M, Haberl N, Gibson N. Quantitative biokinetics over a 28 day period of freshly generated, pristine, $20 \mathrm{~nm}$ silver nanoparticle aerosols in healthy adult rats after a single 1(1/2)-hour inhalation exposure. Part Fibre Toxicol. 2020;17(1):21.

60. Jo MS, Kim JK, Kim Y, Kim HP, Kim HS, Ahn K, Lee JH, Faustman EM, Gulumian M, Kelman B, et al. Mode of silver clearance following 28-day inhalation exposure to silver nanoparticles determined from lung burden assessment including post-exposure observation periods. Arch Toxicol. 2020;94(3):773-84

61. Moriya S, Komatsu S, Yamasaki K, Kawai Y, Kokuba H, Hirota A, Che XF, Inazu M, Gotoh A, Hiramoto M, et al. Targeting the integrated networks of aggresome formation, proteasome, and autophagy potentiates ER stressmediated cell death in multiple myeloma cells. Int J Oncol. 2015;46(2):474-86.

62. Rosario F, Hoet $P$, Santos $C$, Oliveira H. Death and cell cycle progression are differently conditioned by the AgNP size in osteoblast-like cells. Toxicology. 2016;368-369:103-15.

63. Miranda RR, Bezerra AG Jr, Oliveira Ribeiro CA, Randi MA, Voigt CL, Skytte $L$, Rasmussen KL, Kjeldsen F, Filipak Neto F. Toxicological interactions of silver nanoparticles and non-essential metals in human hepatocarcinoma cell line. Toxicol In Vitro. 2017;40:134-43.

64. Kim CH, Jeon HM, Lee SY, Jeong EK, Ju MK, Park BJ, Park HG, Lim SC, Han $\mathrm{SI}$, Kang HS. Role of reactive oxygen species-dependent protein aggregation in metabolic stress-induced necrosis. Int J Oncol. 2010;37(1):97-102.

65. Chaudhary P, Sharma R, Sharma A, Vatsyayan R, Yadav S, Singhal SS, Rauniyar N, Prokai L, Awasthi S, Awasthi YC. Mechanisms of 4-hydroxy2-nonenal induced pro- and anti-apoptotic signaling. Biochemistry. 2010;49(29):6263-75.

66. Redza-Dutordoir M, Averill-Bates DA. Activation of apoptosis signalling pathways by reactive oxygen species. Bba-Mol Cell Res. 2016:1863(12):2977-92.

67. Doll S, Proneth B, Tyurina YY, Panzilius E, Kobayashi S, Ingold I, Irmler M, Beckers J, Aichler M, Walch A, et al. ACSL4 dictates ferroptosis sensitivity by shaping cellular lipid composition. Nat Chem Biol. 2017;13(1):91-8.

68. Friedmann Angeli JP, Krysko DV, Conrad M. Ferroptosis at the crossroads of cancer-acquired drug resistance and immune evasion. Nat Rev Cancer. 2019;19(7):405-14

69. Xu T, Ding W, Ji X, Ao X, Liu Y, Yu W, Wang J. Molecular mechanisms of ferroptosis and its role in cancer therapy. J Cell Mol Med. 2019;23(8):4900-12.

70. Gondikas AP, Morris A, Reinsch BC, Marinakos SM, Lowry GV, Hsu-Kim H. Cysteine-induced modifications of zero-valent silver nanomaterials: implications for particle surface chemistry, aggregation, dissolution, and silver speciation. Environ Sci Technol. 2012;46(13):7037-45.

71. Yu SJ, Chao JB, Sun J, Yin YG, Liu JF, Jiang GB. Quantification of the uptake of silver nanoparticles and ions to HepG2 cells. Environ Sci Technol. 2013;47(7):3268-74

\section{Publisher's Note}

Springer Nature remains neutral with regard to jurisdictional claims in published maps and institutional affiliations. 